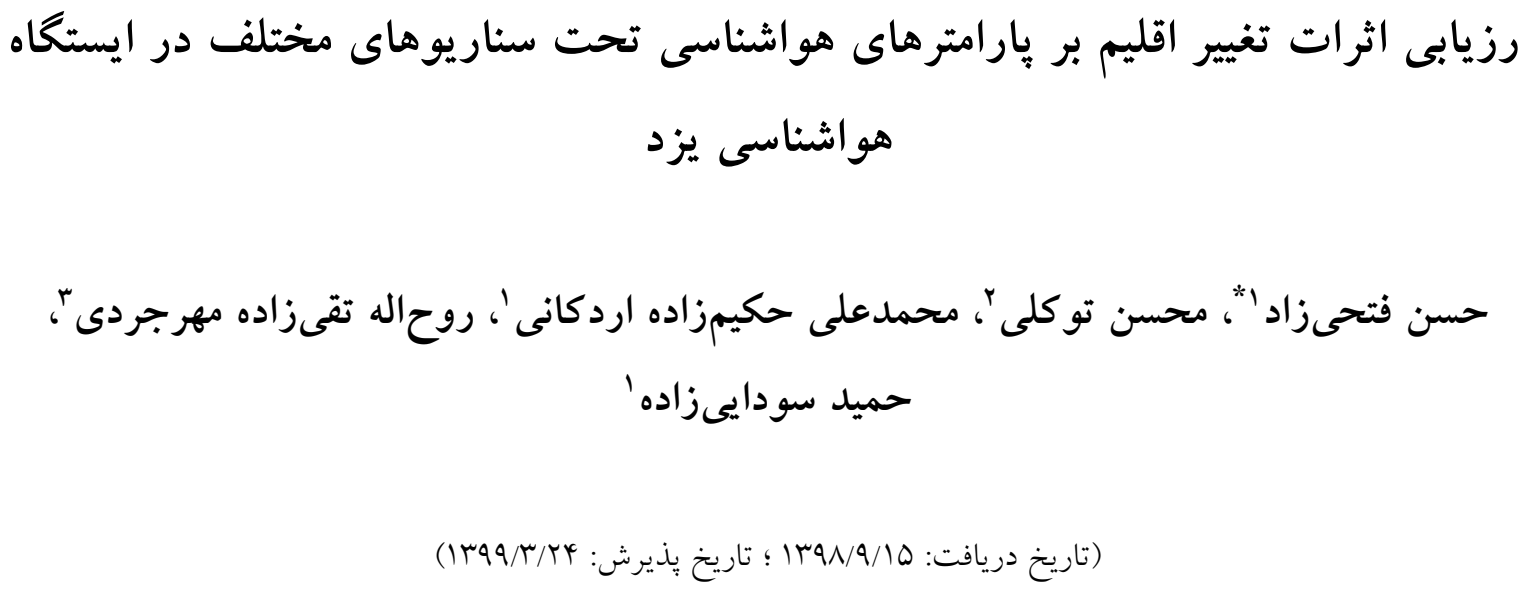

جكيده

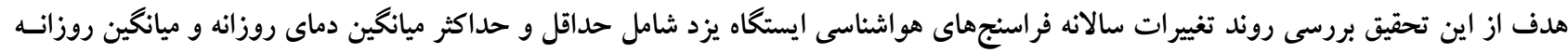

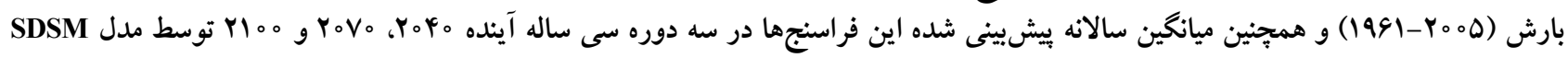

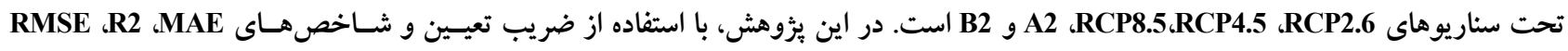

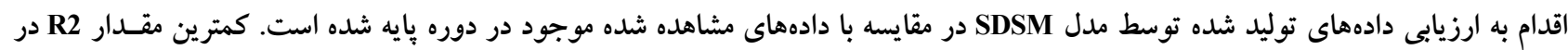

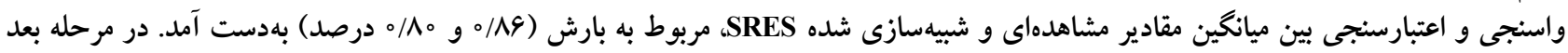

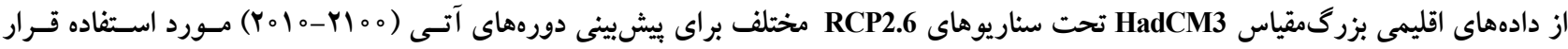

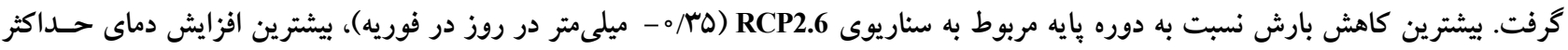

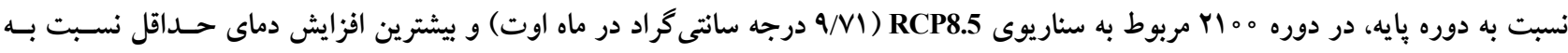

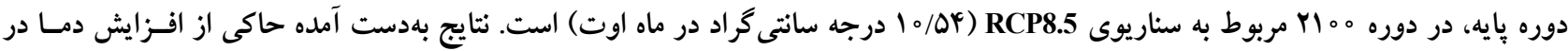

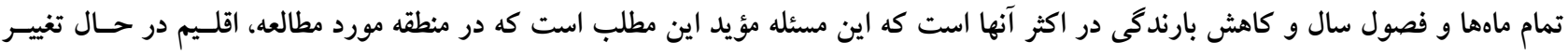




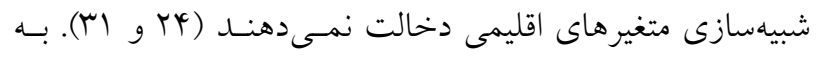

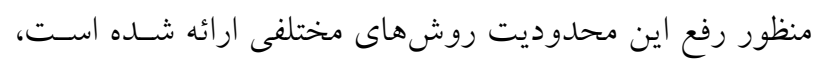

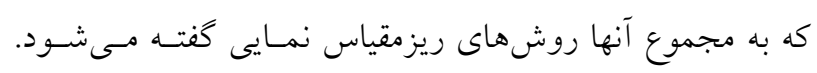

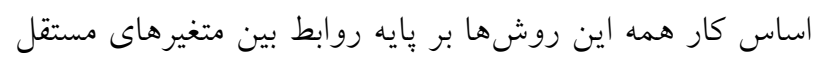

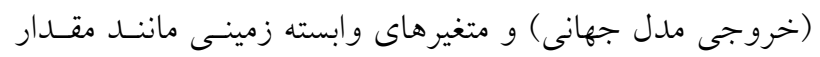

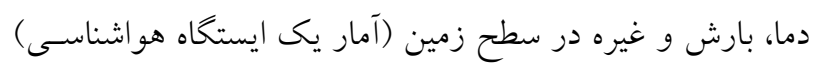

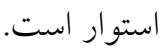
در يـك تقسـيمبنـدى كلـى ايـن روشهـا در جهـار كـروه

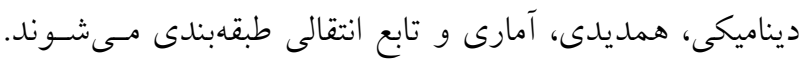

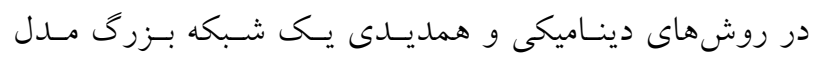

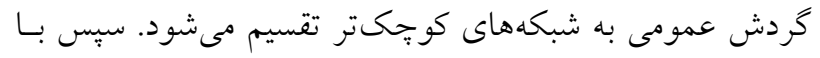

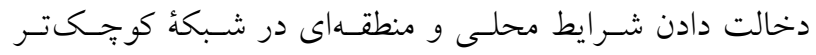

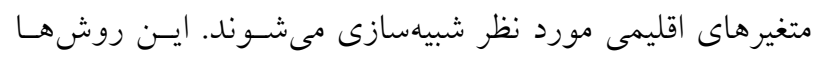
نياز به كارشناسان با تجربه، سيستمهـاى كـامييوترى يِيشـرفته و و

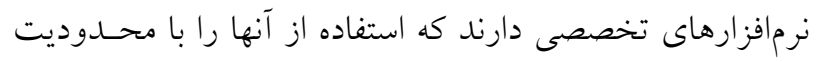

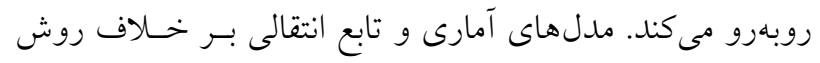

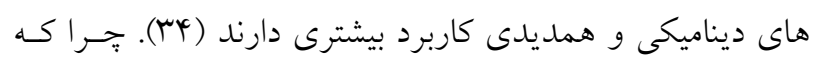

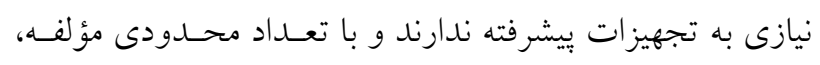

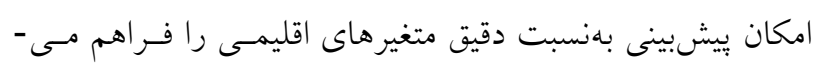

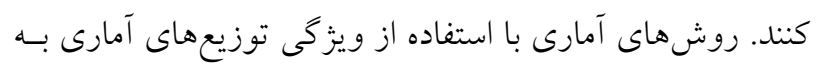

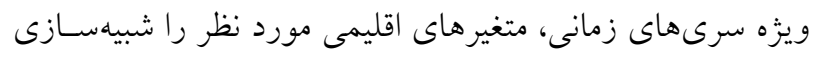

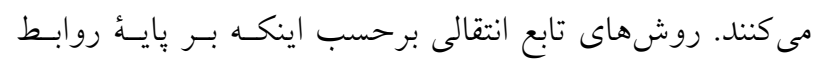

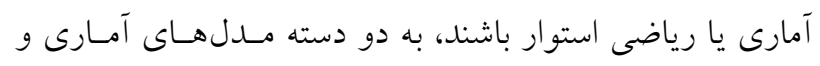
مدلهاى رياضى تقسيمبندى مىشوند.

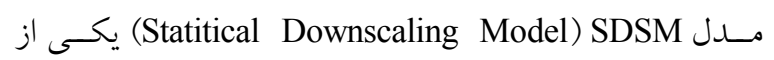

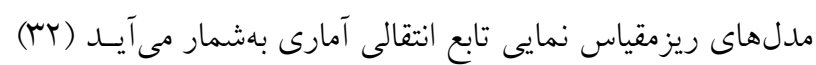

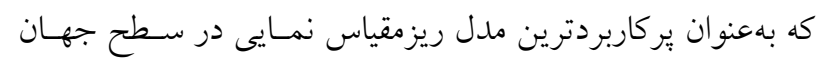

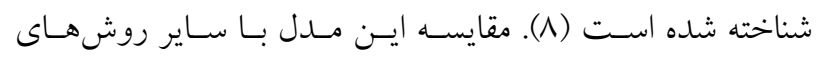

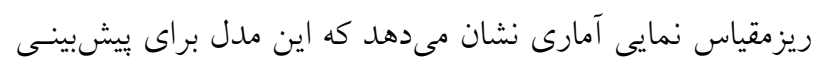

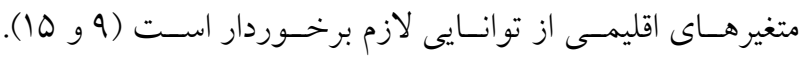

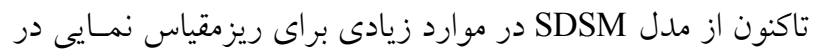
مطالعات مختلفى استفاده شده است (ا و Y).

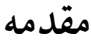

امروزه موضوع تغيير اقليم بـهدليـل بيامــهاى زيسـتمحيطىى،

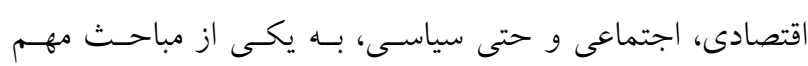

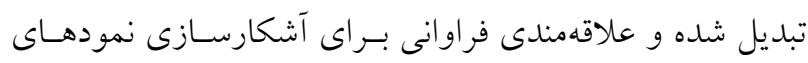

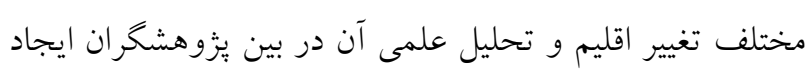

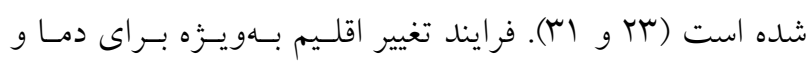
بارندگى مهمترين مبحث مطرح در قلمرو علـوم محيطى اسـت

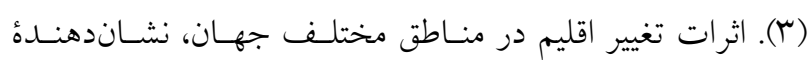

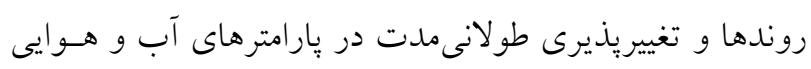

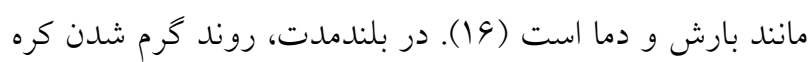
زمين بهخصوص در مناطق نيمهخشك افزايش يافتـه اسـت (11)

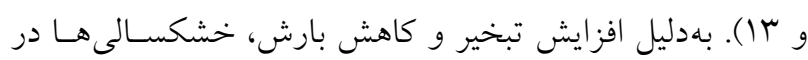

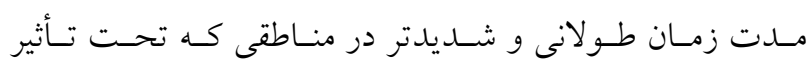

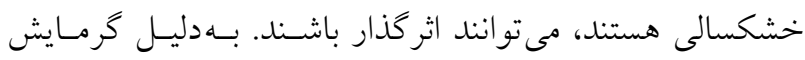

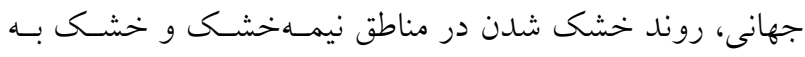

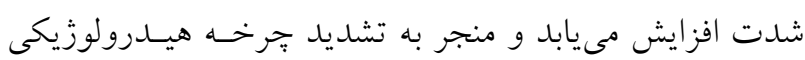

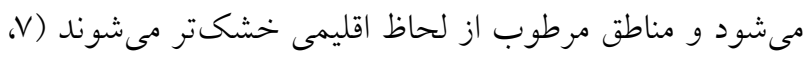
. (TO g )

در دهلهاى اخير، ارزيابى مؤلفههـاى اقليمس در دورههـاى

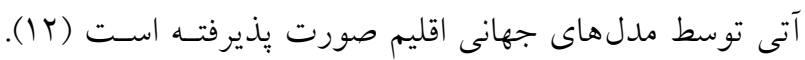

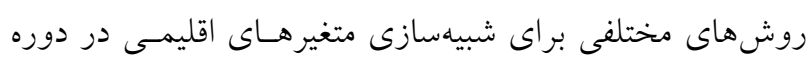

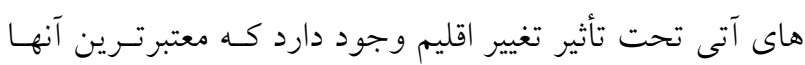

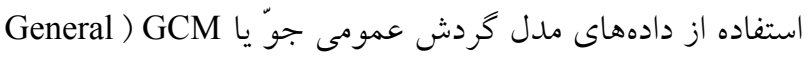

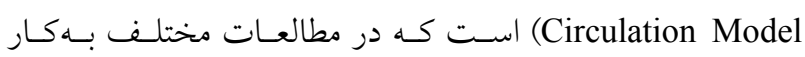

$$
\text { كرفته شده است (19 و 9 Y). }
$$

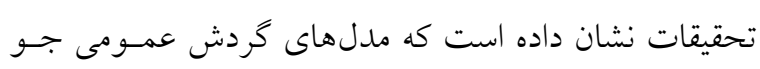

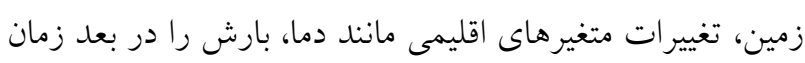

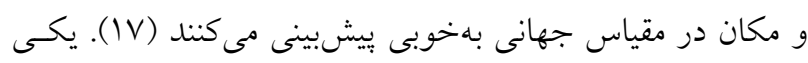

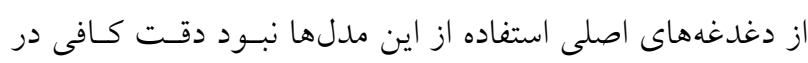

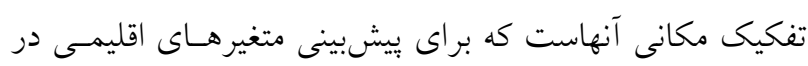

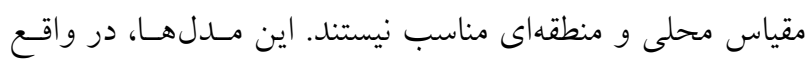

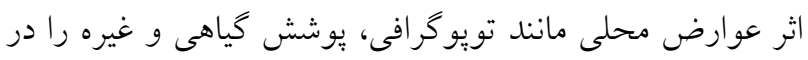


عمده در درجه حرارت، سطح دريا و يا ذوب شـدن يـخ شـود. سـناريوهاى RCPs (RCP8.5، RCP2.6،RCP4.5 ) در ســال

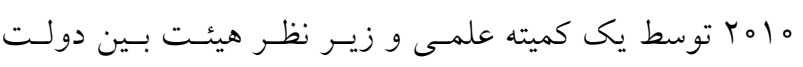
تغييرات اقليمى با هدف مهيا كردن مجموعهاى از اطلاعاتى كـهـ از نتايج آن بتوان عوامل اصلى تغييرات اقليمى را رديابى و نتايج مديج

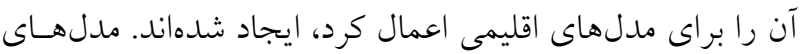

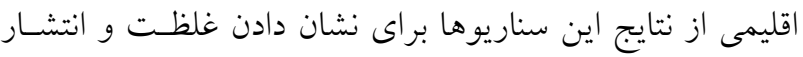

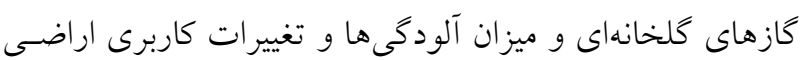

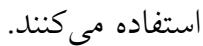
اين سناريوها بر اساس نتايج حاصل از برخى فراسـنجهـاى

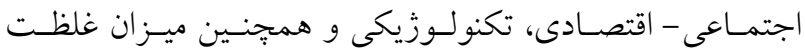
برخى كازها براى دهلهاى آينده طراحى شدهانـــ در سـناريوى

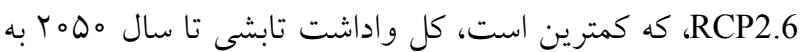

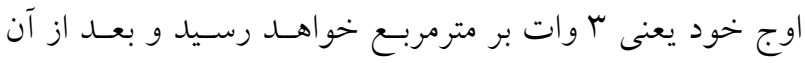

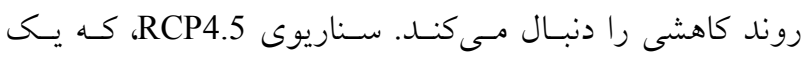
سناريوى ثابت با افزايش نيروى واداشـت تابشى كـل تــا سـال

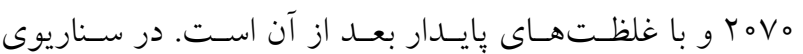

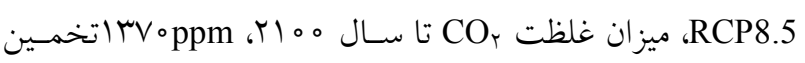

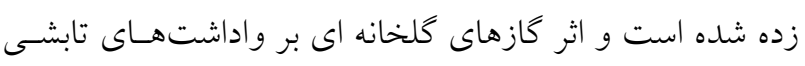

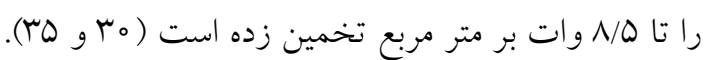

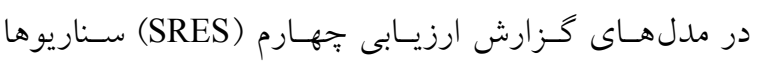

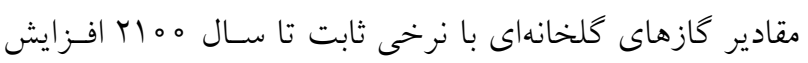

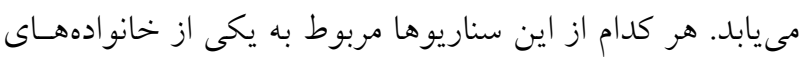

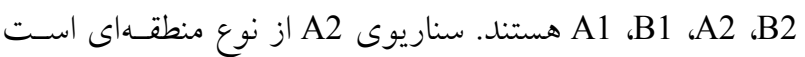

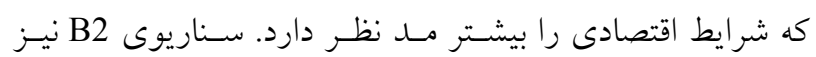
همانند سناريوى A2 منطقهاى اسـت كـه بـه امـر حفـظ محسيط زيست توجه بيشترى دارد (T9).

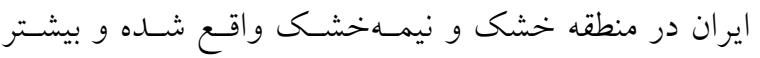
توسط بارندىى كم و درجه حـرارت بـالا شــاخته شـــه اسـت. ناهنجارى ها در درجه حرارت و بارش در ايران نقش مهمى در

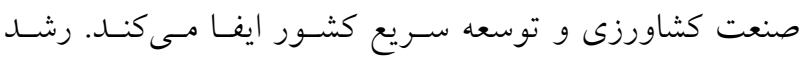

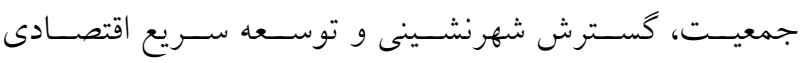

مدلهاى GCM بهعنوان مدلهاى عددى كه فر ايندهاى فيزيكى

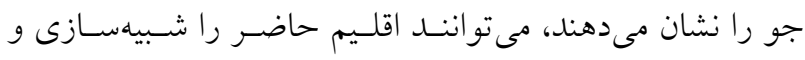

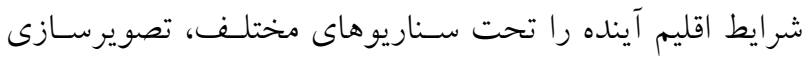

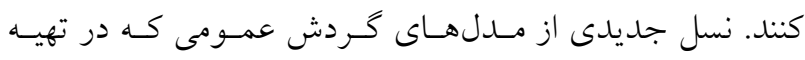

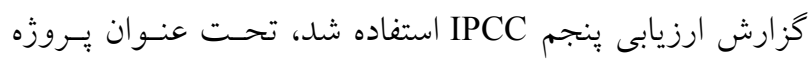
درون مقايسهاى مدلهاى جفت شــه (CMIP5) شـناخته شــه

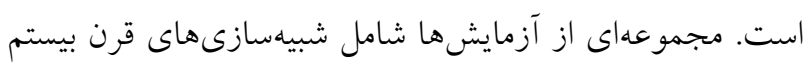

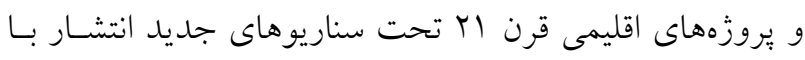

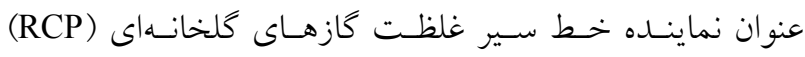

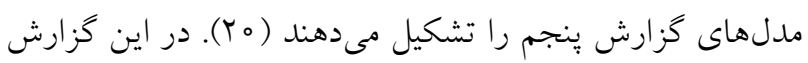

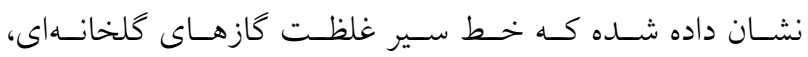
مسيرهاى انتشار را بر اساس تصميمات سياسى متفـاوت فـرض

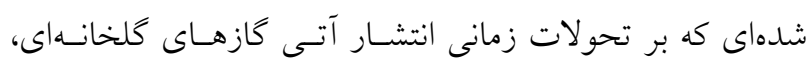

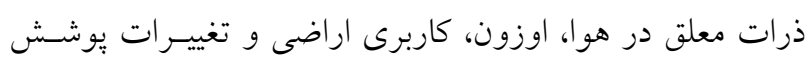

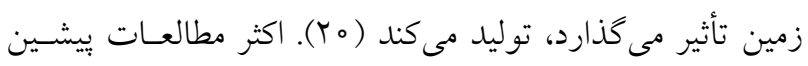

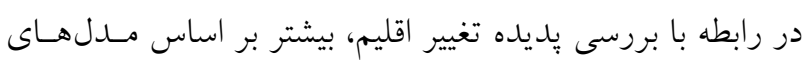

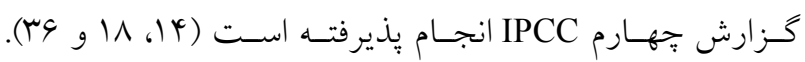

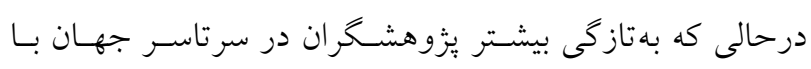

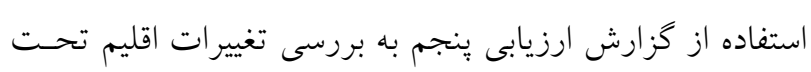

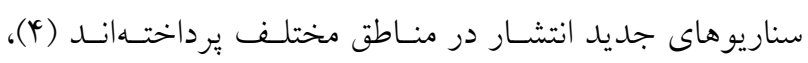

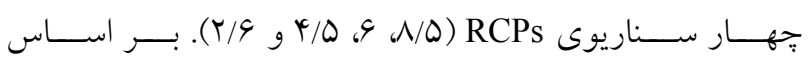
سناريوهاى انتشار كازهايى كه در مقالات منتشر شدهاند انتخاب

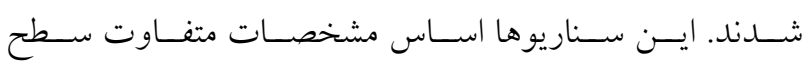
تكنولوزى، وضعيت اجتماعى و اقتصادى، خط مشىها در آينده

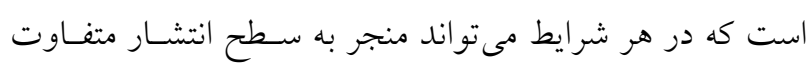

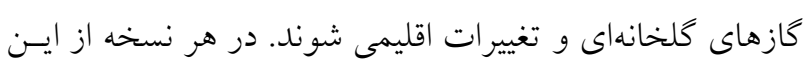

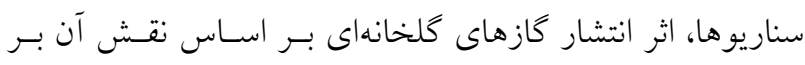

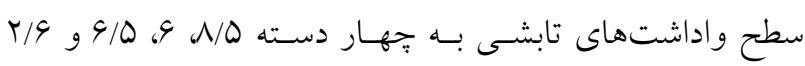
(W/m²

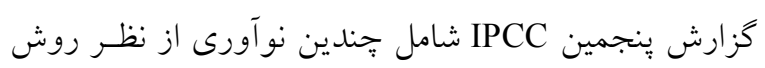

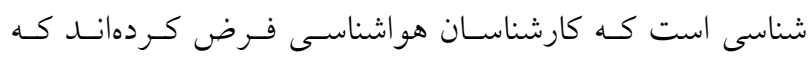

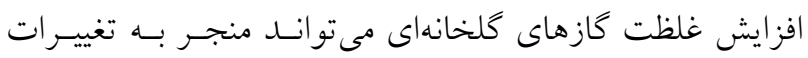




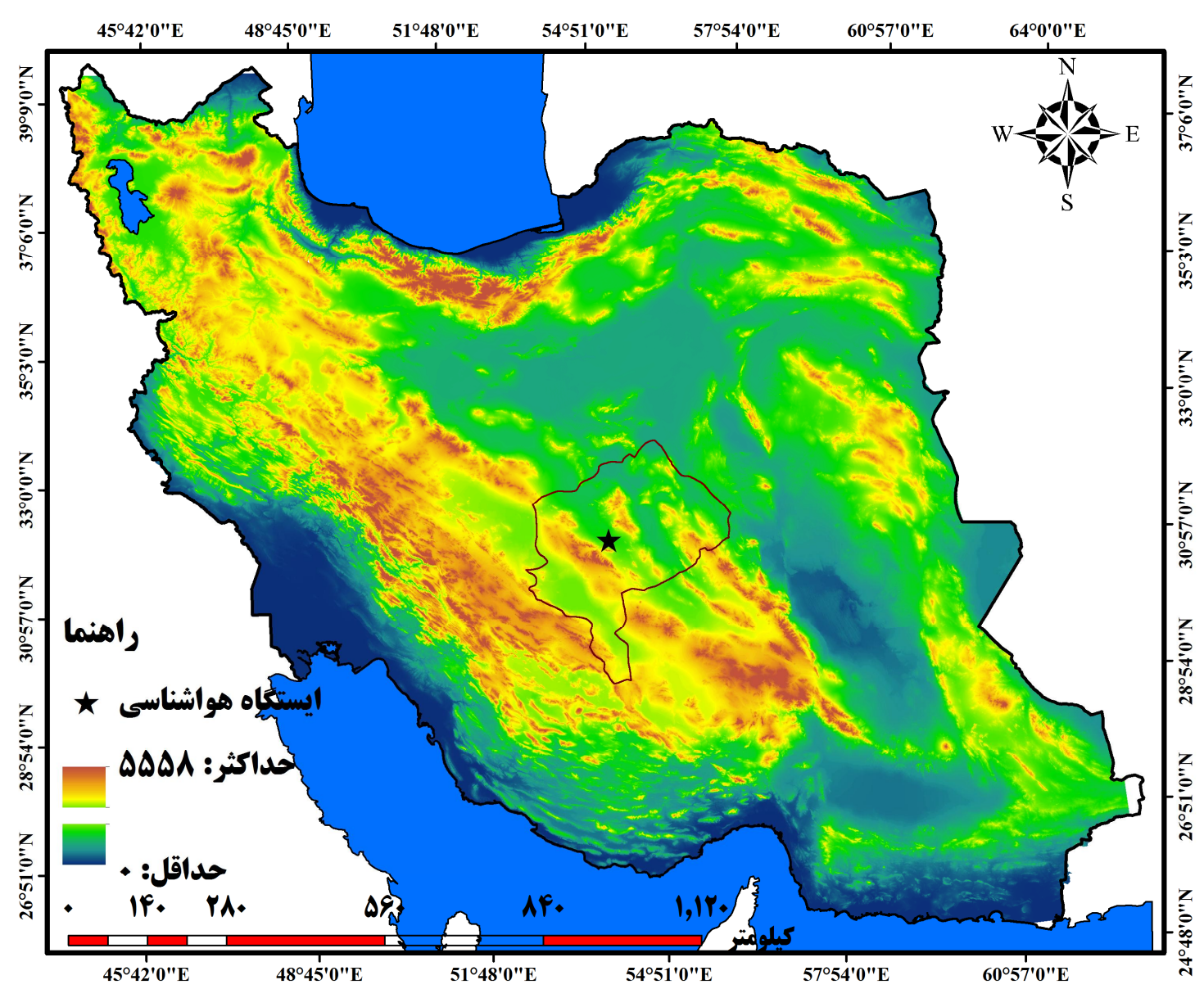

شكل ا. موقعيت ايستخاه هواشناسى يزد در كشور ايران و استان يزد

نشان مى دهد كه ايران با جـالشهـاى كسـترداى در منـابع آب در ايستخاه يزد است.

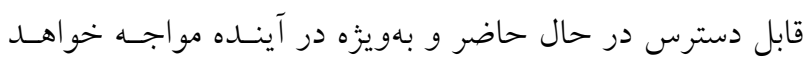

مو اد و روش ها

منطقه مورد مطالعه

ايسـتخاه يــزد در موقيـت جغرافيـايى N N " N

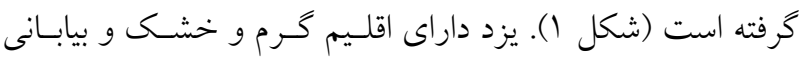
است و نوسان دما در تابستان و زمسـتان و حتسى در شـب و روز بالا و متغير است و اين از ويزگى هاى آب و هوايى منطقه بهشمار مىرود. يزد داراى دو فصل بلند گرما (از اسفند تـا مهر) و كوتـاه

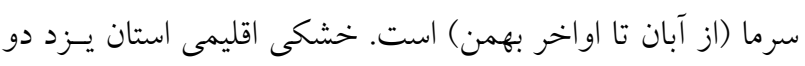
علت اساسى و عمده دارد: يكى اينكه روى كمربند خشك جهانى بود. استان يزد بهدليل واقع شدن در منطقه خشك و رشـد قابـل ملاحظه جمعيت و صنعت، از نظر منابع آبى بسيار مسورد توجـه برنامهريزان بوده است. بنابراين بهنظر مىرسد كه مطالعـه تغييـر اقليم در اين منطقه توسط مدلهاى اقليمى با وضـوح بـالا و بـــ ويزه توسط مدلهاى گزارش قينجم و تحت سـناريوهاى جديــ انتشار امرى ضرورى بهنظر مىرسد. بهطورى كه مدلهاى فـوق مى توانند درى بهترى از ايـن منـاطق در دورههـاى زمـانى آتى نسبت به مدلهاى بيشين هيأت بين الدول تغيير اقليم (كـزارش سوم و جهارم) براى مديران و برنامهريزان منابع آب فراهم كنند. بنابراين هدف از انجام تحقيـق حاضـر بررسـى تغييـرات اقلـيم تحت سناريوهاى جديدى براى شبيهسازى بارامترهـاى اقليمسى 
هاى مشخص است. اين مدلها، ابـزارى مناسـب و توانـا بـراى

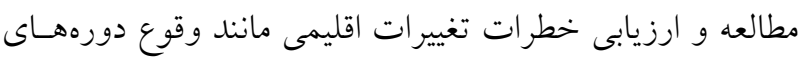

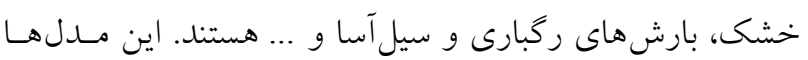

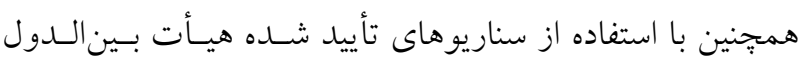
تغيير اقليم، مىتواند اقليم حاضر را شبيهسازى و شــايط اقلـيم

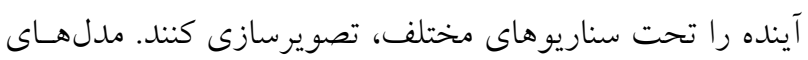

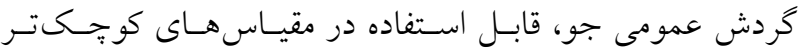
نيستند، لذا نيازمند به ريزمقياس نمايى هستند.

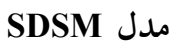
مدل SDSM مدلى كو:كمقياس كننده آمارى اسـت و قابليـت

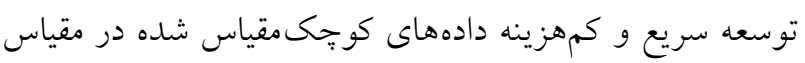
ايستخاهى بهصورت روزانه، ماهانه، فصسلى و يـا سـاليانه را دارا

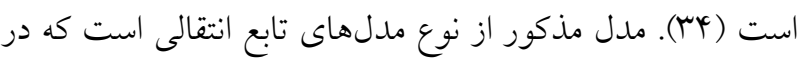

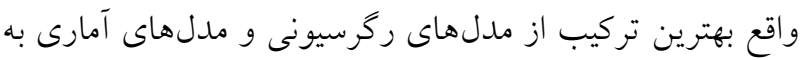

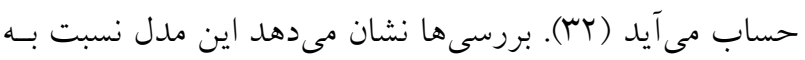
ساير مدلهاى ريزمقياس نمايى نتايج رضـايتبخشى دي در شـبيه

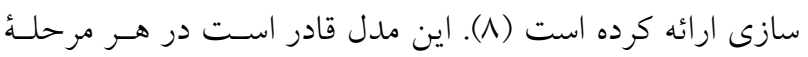

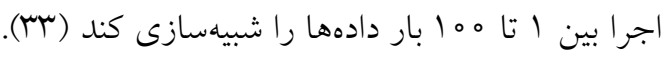

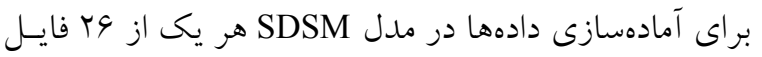
دادههاى بزرگمقياس NCEP نيز همانند دادههاى مشاهده شــده براى انجام واسنجى مدل به دو دوره (r 1994-1991) و (1990-

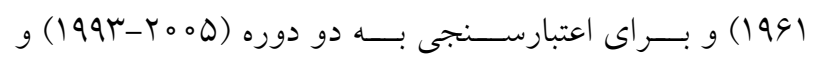

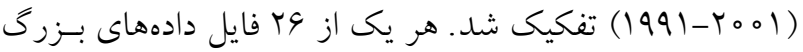
مCP ،H3B2a (1961-2099)، H3A2a (1961-2099) مقيـ

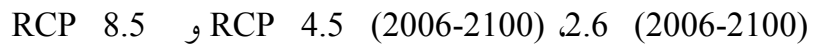
2006-2100) براى مرحله ييشبينى به سه دوره 2040s، و 2100s تفكيك شدند و دوره 1990-1991 بهعنوان دوره بايسه

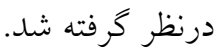

انتخاب متغيرهاى مستقل براى بيشبينى متغيرهاى وابسته

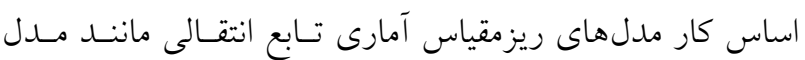

قرار دارد و ديخر آنكه از درياهـاى آزاد عمـان و خلـيجفــارس و درياجههاى داخلى و بادهاى رطوبتزاى دريايى دور است. عامل

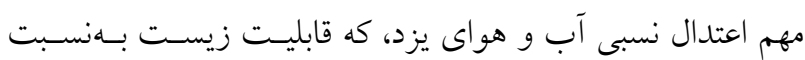

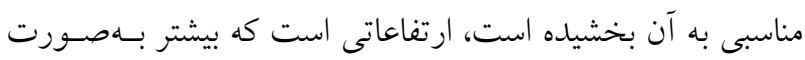

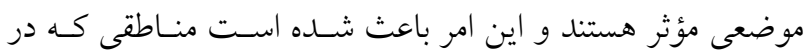

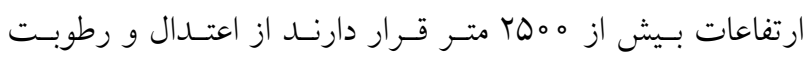
بيشترى نسبت به دشتهاى يزد و اردكان برخوردار باشند.

روش تحقيق

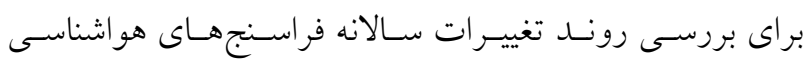

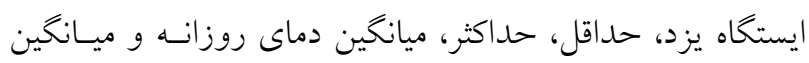

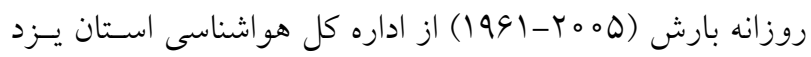

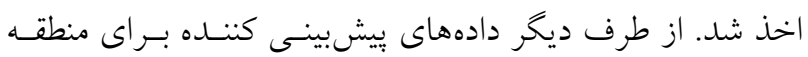

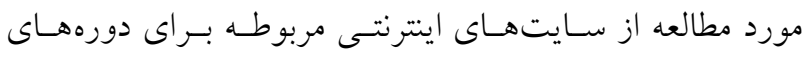

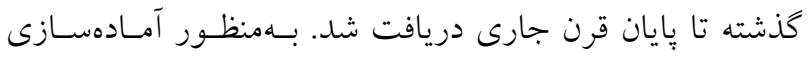

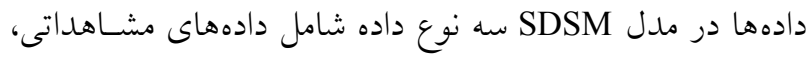

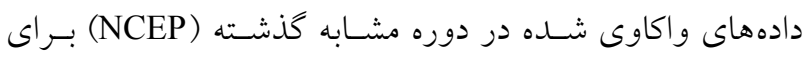

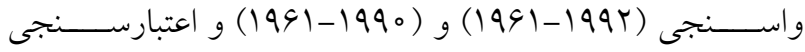

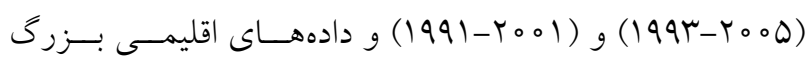
مقياس HadCM3 و ريزمقياس نمايى SDSM تحت سناريوهاى

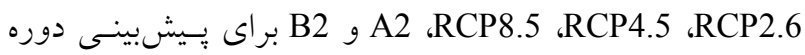

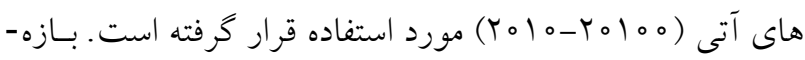
هاى زمانى انتخاب شده براى واسنجى و اعتبارسـنجى بــه ايسن

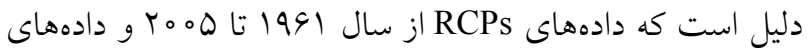
SRES

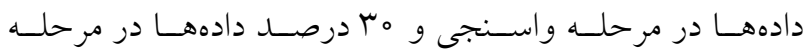
اعتبارسنجى استفاده شدهاند. - اندا

\section{(GCM) مدلهاى گردش عمومى}

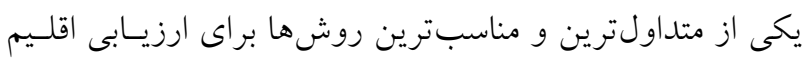

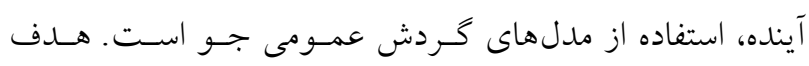

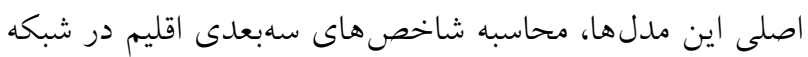


جدول ا. خلاصهاى از خصوصيات سناريوهاى مورد استفاده در اين تحقيق

\begin{tabular}{|c|c|}
\hline خصوصيات & سناريو \\
\hline واداشت تابشى ناشى از آن است. مطابق اين سناريو واداشت تابشى در اواسط اين قرن به حدود //T رسيده و سيس كاهش يافته و & RCP2.6 \\
\hline 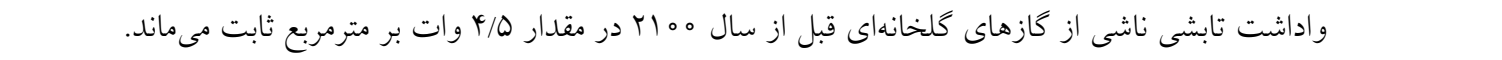 & RCP4.5 \\
\hline 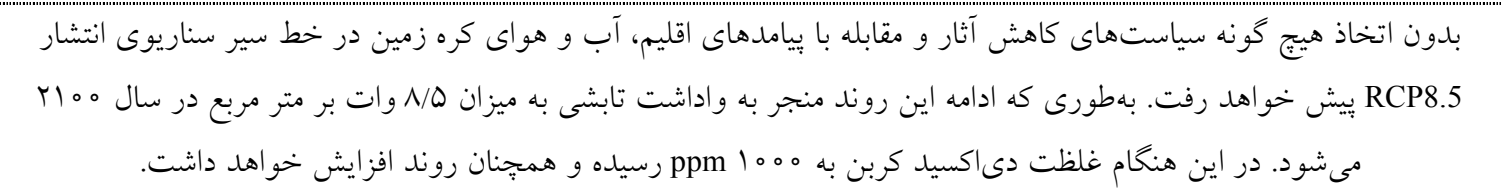 & RCP8.5 \\
\hline
\end{tabular}

(و نه جهانى)

سناريوهاى تغيير اقليم جون يسيشبينس وضـعيت اقلـيم مشـكل اسـت، راه جـايخزين، مشخص كردن وضعيت هاى ممكن آينده بـوده كـه سـناريوهاى اقليمى ناميده مىشوند، اما بايد توجه داشت كـه يـك سـناريوى اقليمى، يك بيشبينى كنندهُ آب و هوا نيست. در اين مطالعسه از سـناريوهاى RCP2.6، RCP8.5، RCP4.5 و B2 R2 اسـتفاده شــه اسـت. در جــدول ا، خلاصسهاى از سـناريوهاى RCP و SRES

نتايج مدل SDSM پِ از وارد كردن دادههـاى مشـاهداتى و مقـادير متناظر NCEP، يارامترهايى كه بالاترين تأثير را بـر شـبيهسـازى داشته و واريـانس بيشـترى را توضسيح مسى دهنــ را انتخـاب و مشخص مى كند (جدول Y). اين مرحله مهمترين مرحله مدلينخ

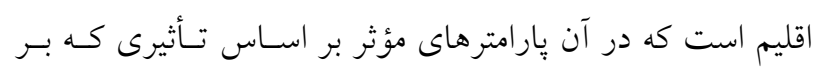
معادله دارند تعيين مىشوند. در اين بزوهش، با استفاده از شاخصهـاى MAE، RMSE، R اقدام به ارزيابى دقت دادههاى شبيهسازى شده دادههاى مشاهده شده موجود در دوره يايه شد. نتايج كو جكىمقياس شده حــداقل و حداكثر ميانخين دماى روزانه و ميانخين روزانه بارش دادههاى
بر بايهُ ارتباط بين متغيرهاى مستقل جـوى و متغيرهـاى SDSM وابسته ايستخاهى نظير بارش و دما استوار اسـت. در ايسن مـورد انتخــاب متغيرهـاى مسـتقل كـهـ ارتبــاط منطقـى و مناسـبى بــا متغيرهاى وابسـته داشـته باشــند، از اهميـت خاصسى برخــوردار است.

\section{واسنجى و اعتبارسنجى مدل}

بهمنظور كاليبره كردن مدل SDSM دادههاى مورد استفاده بـه دو

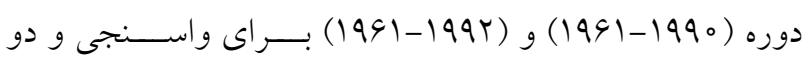
دوره (| شدند. براى كـاليبره كـردن مــدل از روش بهينـهسـازى حـــاقل مربعات استفاده شد. بعد از كاليبره كردن مدل بهمنظـور حصـول اطمينان از اينكه مدل توانـايى شـبيهسـازى دادههـا را خــارج از محدودهُ زمانى كاليبراسيون دارد، نياز است مدل ارزيـابى شـود. بلدين منظور با استفاده از مدل SDSM كاليبره شده، بارامترهـاى حداقل و حداكثر ميانخين دماى روزانه و ميانخين روزانه بـارش

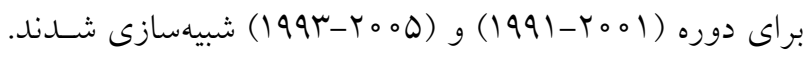
سبِ با مقايسة دادههاى مشاهدهاى و دادههاى شبيهسازى شده، كارايى مدل براى ايستخاه يزد مورد بررسى قرار گرفت. در ايسن تحقيق بهمنظور بررسى ميزان كارايى مدل از ضـريب تعيسين Rئ

استفاده شد. 
جدول r. مهم ترين متغيرهاى بيشبينى كننده ايستخاه مورد مطالعه

\begin{tabular}{|c|c|c|c|c|c|c|c|}
\hline \multicolumn{3}{|c|}{ RCP (1961-2005) } & \multicolumn{3}{|c|}{ SRES (1961-2001) } & \multirow[b]{2}{*}{ اسم متغير } & \multirow[b]{2}{*}{ متغير } \\
\hline حداقل درجه & حداكثر درجه & 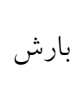 & حداقل درجه & حداكثر درجه & 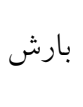 & & \\
\hline & & & & & $*$ & Vorticity at $850 \mathrm{hPa}$ height & ncepp8_zas \\
\hline & & & $*$ & $*$ & $*$ & Relative humidity at $850 \mathrm{hPa}$ height & ncepr850as \\
\hline & & & $*$ & $*$ & $*$ & Near surface relative humidity data & nceprhumas \\
\hline & $*$ & $*$ & & & $*$ & Surface specific humidity & ncepshumas \\
\hline$*$ & $*$ & $*$ & & & & Specific humidity at $500 \mathrm{hPa}$ & ncepp $500 \mathrm{gl}$ \\
\hline$*$ & & $*$ & & & & $500 \mathrm{hPa}$ geopotential height & nceps $500 \mathrm{gl}$ \\
\hline & & $*$ & & & & Specific humidity at $850 \mathrm{hPa}$ & nceps $850 \mathrm{gl}$ \\
\hline & & & $*$ & * & & Mean sea level pressure & ncepmslpas \\
\hline & $*$ & & $*$ & $*$ & & $500 \mathrm{hPa}$ geopotential height & ncepp500as \\
\hline$*$ & $*$ & & $*$ & $*$ & & Mean temperature at $2 \mathrm{~m}$ & nceptempas \\
\hline$*$ & $*$ & & & & & Mean sea level pressure & ncepmslpgl \\
\hline & & & & & & $850 \mathrm{hPa}$ geopotential height & ncepp850as \\
\hline$*$ & & & & & & $500 \mathrm{hPa}$ vorticity & ncepp5_zgl \\
\hline
\end{tabular}

هوا در اين فصل دانست كه از نظم خاصى بيروى نمى كنــد بــه همين دليل مدل توانايى لازم بـراى شـبيهسـازى بـارش در ايسن فصل را ندارد. كاهش خطاى مدل در فصل تابستان را مسىتـوان ناشى از نبود بارش دانست كه مدل هم توانايى شبيهسازى آن را بهخوبى دارد. نمودار نتايج كو جكمقياس شده حداقل و حداكثر ميانخين دماى روزانه و ميانخين روزانه بـارش دادههـاى RCP و SRES اعتبارسنجى ارائه شده است. بيشبينى پارامترهاى اقليمى آينده بـ از ارزيابى مدل، با توجه به متغيرهاى انتخـاب شــده، سـرىهـاى زمانى بارامترهاى اقليمى توليد شده است. شكلهاى ^و 9 و و جـدول

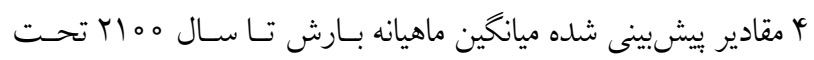
سناريوهاى مختلف RCPs در مقايسه با دوره بايه را نشـان مـىدهــ. تحت سناريوى RCP2.6 براى هر سه دوره در ماههاى آوريـل، مسى و اكتبر شاهد افـزايش ميـزان بـارش و در بقيـه مــاههـا كـاهش بـارش بيشينى شده است. تحت سناريوهاى RCP8.5 و RCP4.5 براى هـر سه دوره در ماههاى آوريل، مى، اكتبر، نوامبر و دسـامبر (بـهـهـز دوره

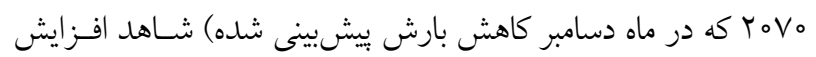

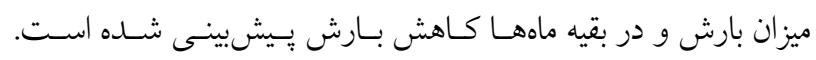

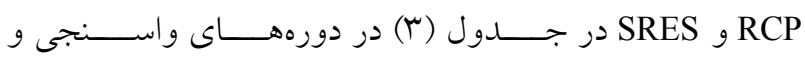
اعتبارسنجى ارائه شده است. كمتــرين مقــار R در واسـنجى و اعتبارسنجى بين ميانخين مقادير مشاهدهاى و شـبيهسـازى شــه SRES يـزد مـدلسـازى ميـانخين دمـاى حسـاقل و حسـاكثر دو دسـته دادههاى RCP و RRES كاملاً با دادههـاى مشـاهداتى مطابقـت دارند. از نظر شاخص ارزيابى R²، دقـت نتـايج كوجـــمقيـاس شده دماى ميانخين حــاقل و حـــاكثر بيشـتر از دقـت ميـانگين بارش بوده، ولى از نظر شاخص هاى ارزيـابى MAE و RMSE، دقت نتايج كو جكىمقياس شده ميـانخين بـارش بيشـتر از دقـت دماى ميانخين حداقل و حداكثر بوده است. بهطور كلى، مطلوب بودن مقادير شاخصىهاى ارزيابى و عدم اختلاف معنسىدار بـين مقادير مشاهدهاى و شبيهسازى شده، مؤيد كارايى مناسـب مــل براى شبيهسازى وضعيت اقليمى آينده در منطقسه مـورد مطالعه است. در دورههاى واسنجى و اعتبارسنجى ميانخين روزانه بـارش، ماههاى فصل بهار بيشترين خطا و ماههاى فصـل تابستان داراى كمترين خطا هستند. در واقع خطاى بالاى شبيهسازى در فصل بهار را بايد ناشى از بارشهاى ركبـارى و آشـفتخىهـاى آب و 
نشريه علوم آب و خاك / سال بيست و جهارم / شماره جهارم / زمستان ج991

جدول r. نتايج آمارى شبيهسازى حداقل و حداكثر ميانخين دماى روزانه و ميانخين روزانه بارش

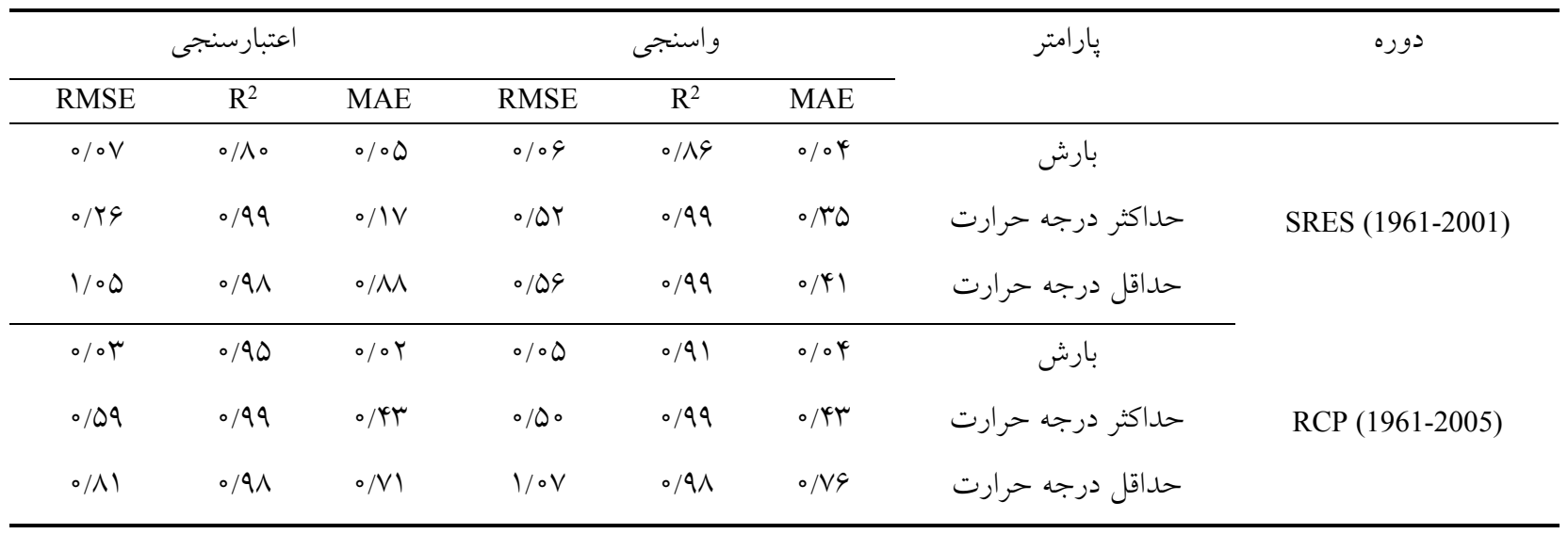
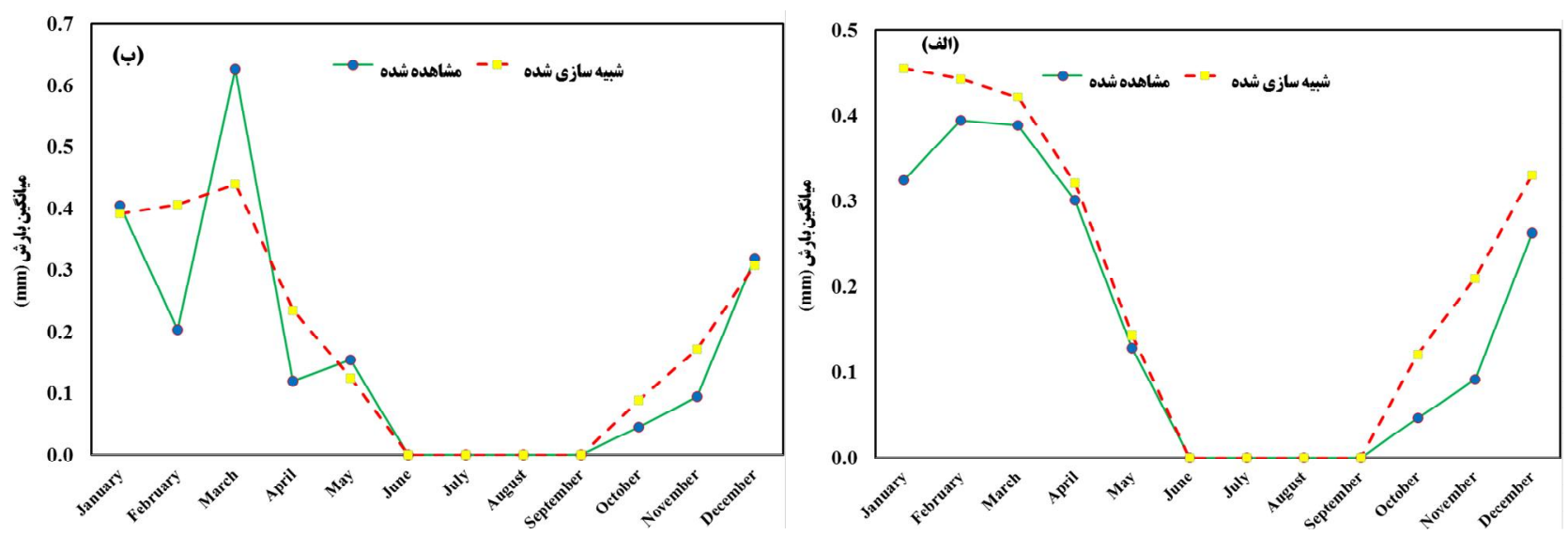

شكل r. نمودار مقايسه ميانگين روزانه بارش مشاهده شده و شبيهسازى شده: الف)دوره واسنجى و ب) اعتبارسنجى سناريوهاى SRES (رنكى در نسخه الكترونيكى)
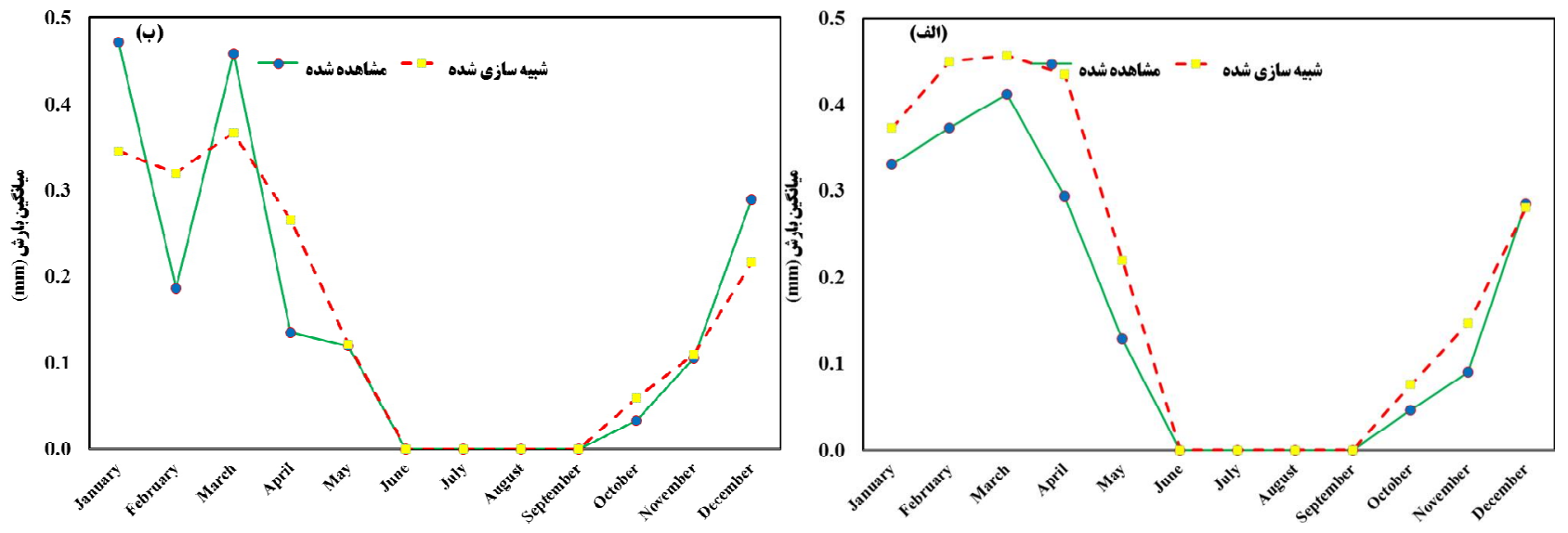

شكل r. نمودار مقايسه ميانگين روزانه بارش مشاهده شده و شبيهسازى شده: الف) دوره واسنجى و ب) اعتبارسنجى سناريوهاى RCP (رنكى در نسخه الكترونيكى)

$\wedge$ 
ارزيابى اثرات تغيير اقليم بر بارامترهاى هواشناسى تحت سناريوهاى مختلف در ...
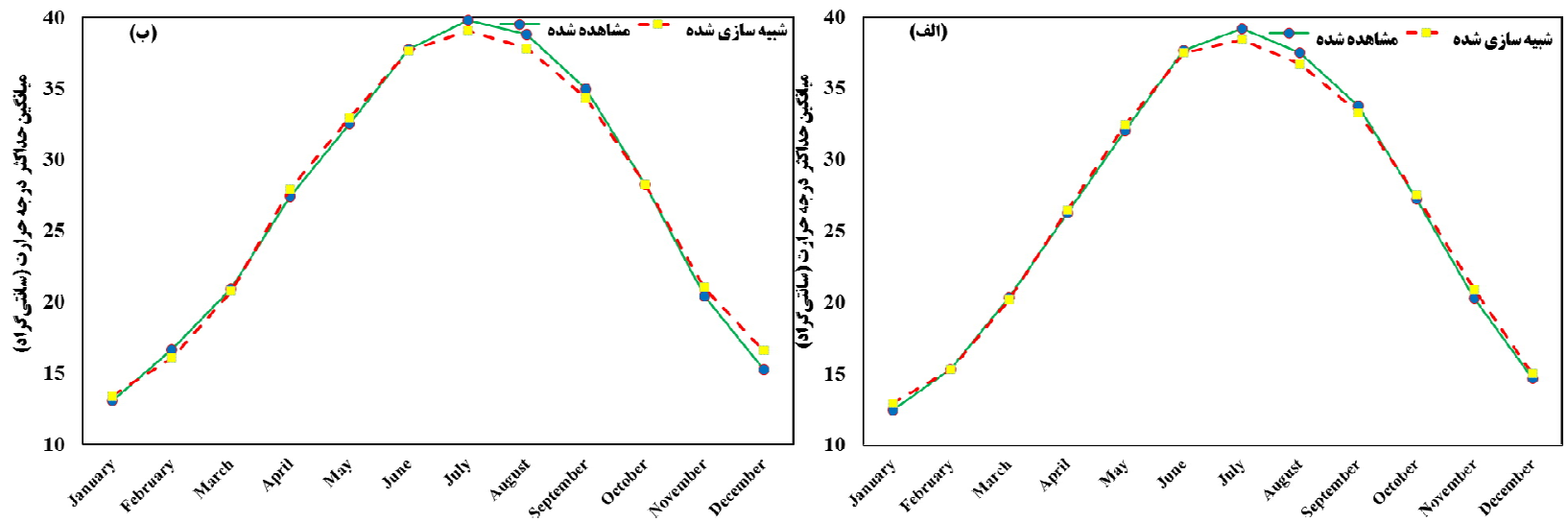

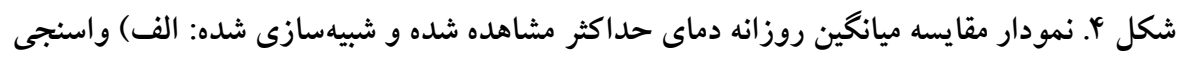
و ب) اعتبارسنجى سناريوهاى SRES (رنكى در نسخه الكترونيكى)
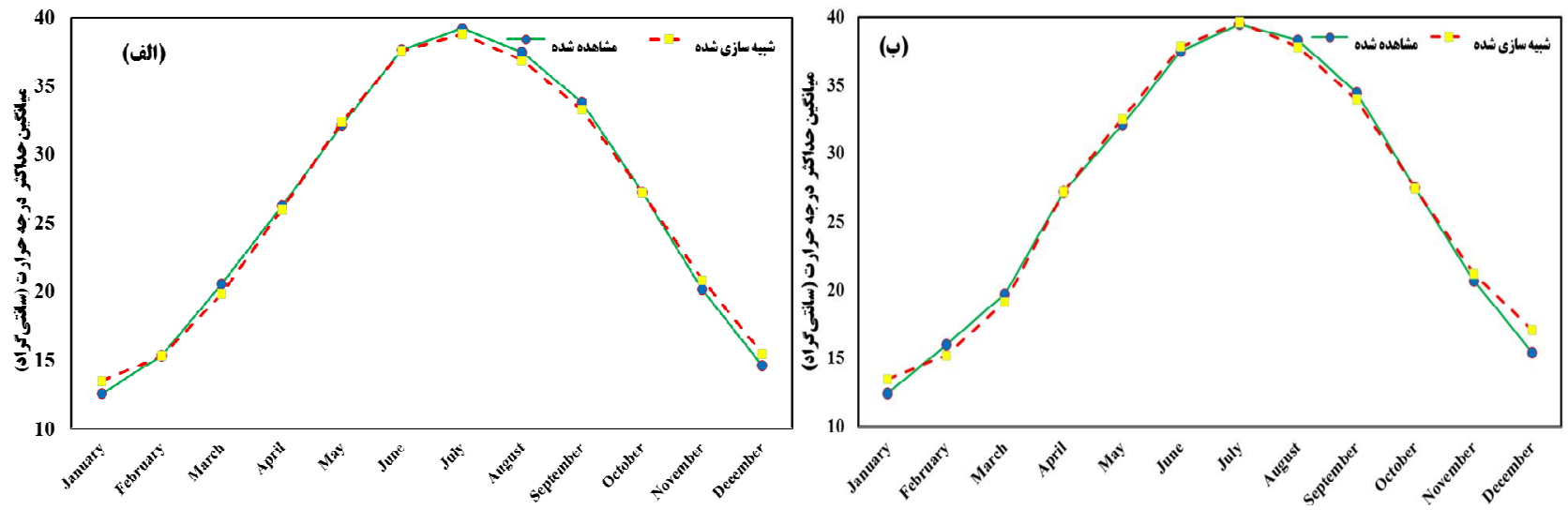

شكل ه. نمودار مقايسه ميانكين روزانه دماى حداكثر مشاهده شده و شبيهسازى شده: الف) دوره واسنجى (رونج وب) اعتبارسنجى سناريوهاى RCP (رنخى در نسخه الكترونيكى)
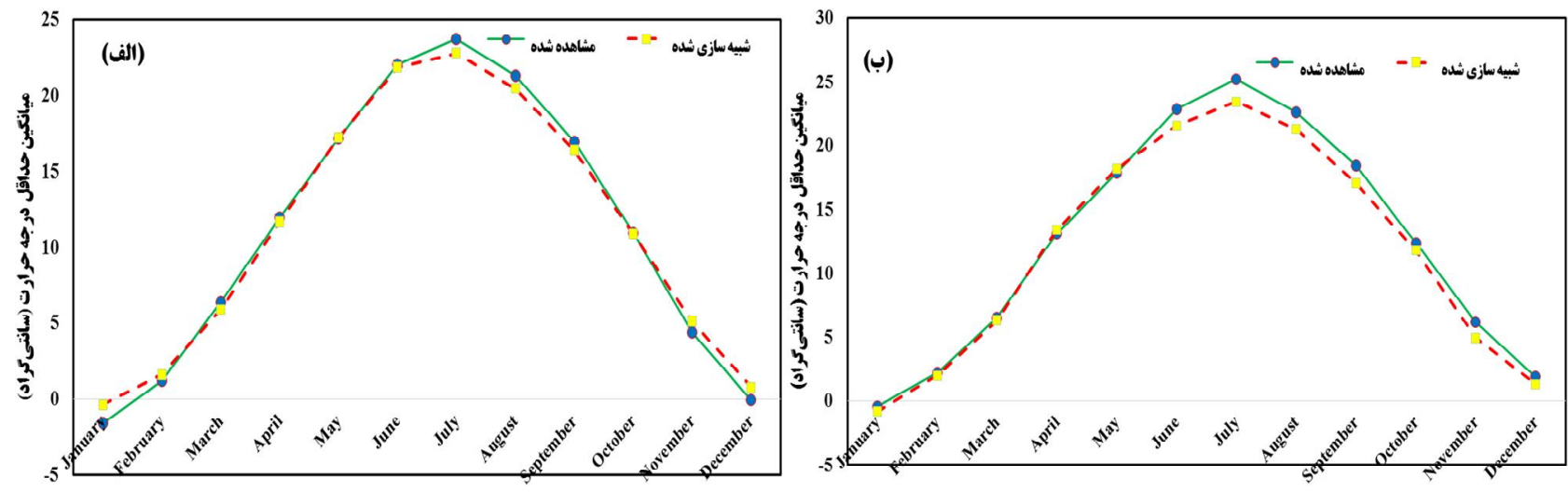

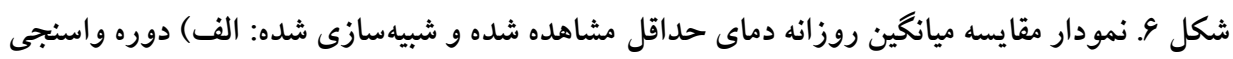
و ب) اعتبارسنجى سناريوهاى SRES (رنكى در نسخه الكترونيكى)

9 

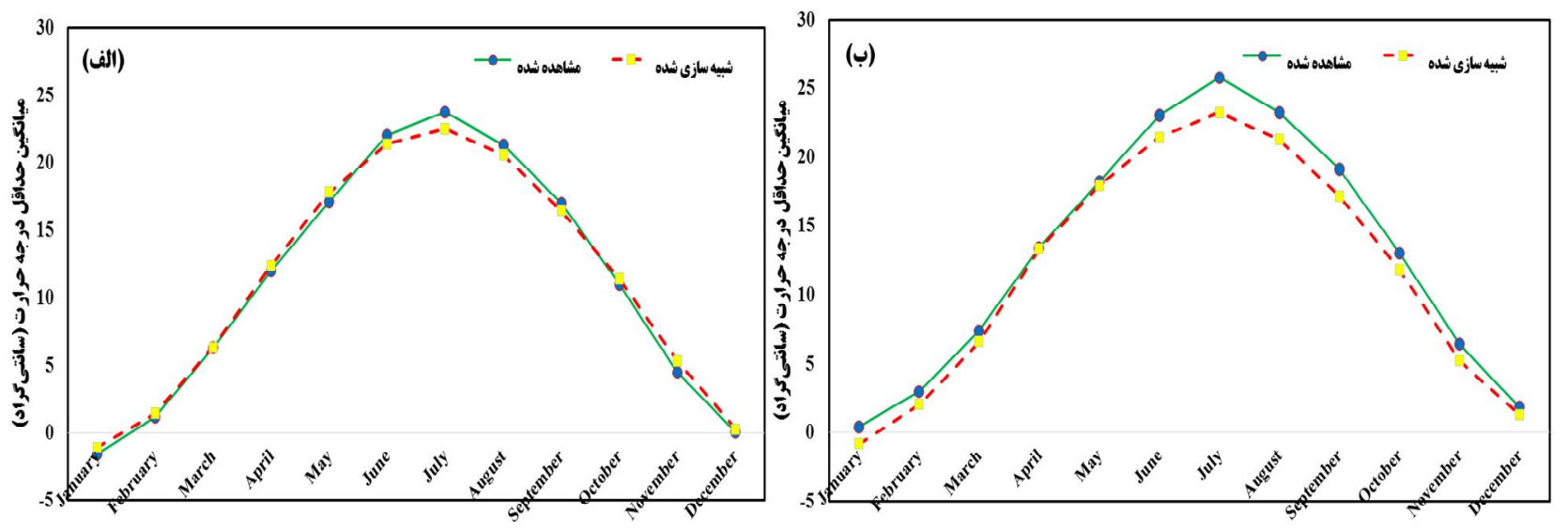

شكل V. نمودار مقايسه ميانگين روزانه دماى حداقل مشاهده شده و شبيهسازى شده: الف) دوره واسنجى

و ب) اعتبارسنجى سناريوهاى RCP (رنكى در نسخه الكترونيكى)
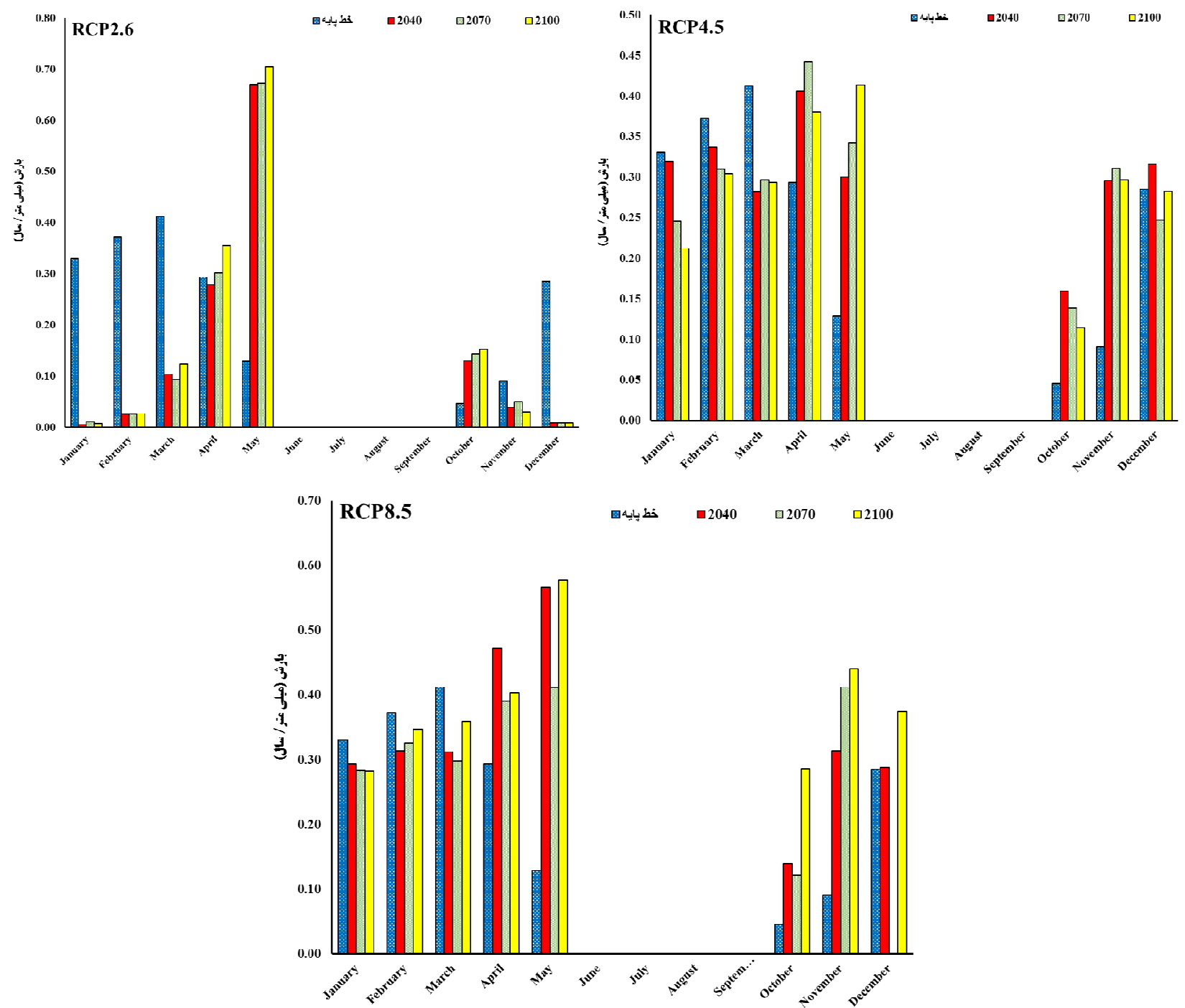

شكل ^ـ ميانخين ماهيانه بارش بيشبينى شده تا بايان قرن جارى براى سناريوهاى RCPs (رنخى در نسخه الكترونيكى) 

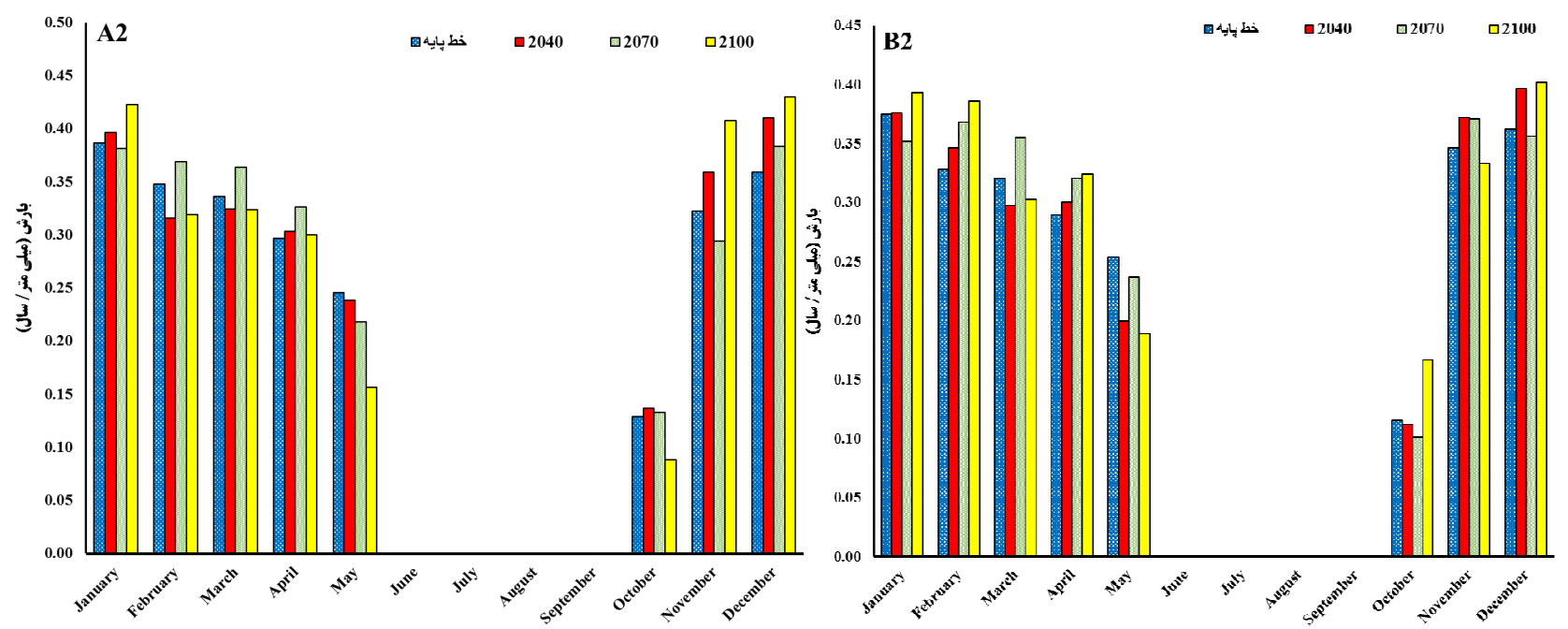

شكل 9. ميانخين ماهيانه بارش بيشبينى شده تا بايان قرن جارى براى سناريوهاى مختلف SRES (رنخى در نسخه الكترونيكى)

جدول f. مقدار تغييرات ميانغين ماهيانه بارش در دورههاى آينده نسبت به دوره پايه تحت سناريوهاى مختلف

\begin{tabular}{|c|c|c|c|c|c|c|c|c|c|c|c|c|c|c|}
\hline سالانه & دسامبر & نو امبر & اكتبر & سيتامبر & اوت & جولاى & زوئن & مى & آوريل & مارس & فوريه & زانويه & دور0 & سناريو \\
\hline $0 / T V$ & $-0 / Y \wedge$ & $-\circ / \circ \Delta$ & $\circ / \circ \wedge$ & $0 / 00$ & $\circ / 00$ & $0 / 00$ & $0 / 00$ & $\circ / Q Y$ & $-0 / 01$ & $-0 / \Gamma_{1}$ & $-0 / \mu_{\Delta}$ & - & Toro & \\
\hline $0 / 01$ & $\circ / 00$ & $0 / 01$ & $0 / 01$ & $0 / 00$ & $\%$ & $\circ / 00$ & $0 / 00$ & $0 / 00$ & \%/० Y & $-0 / 01$ & ०/०。 & $0 / 01$ & Y०V० & RCP2.6 \\
\hline $0 / T 4$ & $-\circ /{ }^{\prime} \wedge$ & $-0 / 09$ & $0 / 11$ & $0 / 00$ & $0 / 00$ & $0 / 00$ & $0 / 00$ & $\circ / \Delta \wedge$ & $0 / 09$ & $-0 / 7 q$ & $-0 / \mu_{0}$ & -o/K & Yolo & \\
\hline $0 / 04$ & .० & $\circ / Y \circ$ & $0 / 11$ & $\circ / 00$ & $\circ / \circ \circ$ & $\circ / 00$ & $\circ / 0 \circ$ & $\circ / \mathrm{V}$ & $0 / 11$ & $-0 / 1 \mu$ & $-0 / 0 \psi^{k}$ & $-0 / 01$ & YoY. & \\
\hline$\circ / \circ \Delta$ & $-0 / 0 \varphi^{f}$ & O/TY & $0 / 09$ & $\circ / 00$ & $\circ / 00$ & $\circ / 00$ & $\circ / 00$ & $0 / Y 1$ &.$/ 10$ & $-0 / 1 Y$ & $-0 / 04$ & $-0 / 0 \wedge$ & $T \circ V \circ$ & $\mathrm{RCP} 4.5$ \\
\hline$\circ / \circ 0$ & $\circ / 00$ & $0 / T 1$ & $\circ / \circ \mathrm{V}$ & $0 / 00$ & $\circ / \circ \circ$ & $\circ / 00$ & $\circ / 0 \circ$ & $\circ / T \wedge$ & $0 / 09$ & $-0 / 1 Y$ & $-\circ / \circ V$ & $-0 / 1 Y$ & Yolo & \\
\hline$\circ / \circ 9$ & $\circ / 00$ & O/Tr & $0 / 09$ & $0 / 00$ & $\circ / \circ \circ$ & $0 / 00$ & $\circ / 00$ & $0 / 4 Y$ & $\circ / 1 \wedge$ & $-0 / 10$ & $-0 / 09$ & $-0 / 04$ & YoY. & \\
\hline$\circ / \circ \wedge$ & $0 / 14$ & ס & $\circ / \circ \wedge$ & $\circ / 00$ & $\circ / 00$ & $\circ / 00$ & $0 / 00$ & $\circ / T \wedge$ & $\circ / 10$ & $-0 / 11$ & $-0 / \circ \Delta$ & $-\circ / \circ \Delta$ & $r \circ V \circ$ & RCP8.5 \\
\hline سוס & $0 / 09$ & $\circ / \Gamma \Delta$ & o/TY & $0 / 00$ & $0 / 00$ & $0 / 00$ & $\circ / 00$ & $\circ / \mathbb{Q}$ & $0 / 11$ & $-0 / 00$ & $-0 / 0 \mu$ & $-\circ / \circ \Delta \omega$ & Tolo & \\
\hline $0 / 01$ & $\circ / \circ \Delta$ & $0 / 04$ & $0 / 01$ & $0 / 00$ & $\circ / 00$ & $0 / 00$ & $0 / 00$ & $-0 / 01$ & $0 / 01$ & $-0 / 01$ & $-0 / 04$ & $0 / 01$ & ToYo & \\
\hline$\circ / 00$ & O/OT & $-0 / 0 \mu$ & $\circ / 00$ & $\circ / 00$ & $\circ / 00$ & $0 / 00$ & $\circ / 00$ & $-0 / 0{ }^{2}$ & $\circ / 04$ & ס & O/OT & $\circ / 00$ & $r \circ V \circ$ & $\mathrm{A} 2$ \\
\hline$\%$ & $\circ / \circ \mathrm{V}$ & $0 / 09$ & $-0 / 0 \psi^{4}$ & $\circ / 00$ & $\circ / 00$ & $\circ / 00$ & $\circ / 00$ & $-0 / 09$ & $\circ / 00$ & $-0 / 01$ & $-0 / 0 \mu$ & $0 / 0 f^{f}$ & Yolo & \\
\hline$\circ / 0 \circ$ & $0 / 04$ & ס & $0 / 00$ & $0 / 00$ & $\circ / 00$ & $\circ / 00$ & $\circ / 00$ & $-0 / \circ 0$ & $0 / 01$ & $-0 / 0 Y$ & $0 / 0 Y$ & $\circ / 00$ & YoYo & \\
\hline $0 / 01$ & $-0 / 01$ & $0 / 0 Y$ & $-0 / 01$ & $\circ / 00$ & $\circ / 00$ & $\circ / 00$ & $\circ / 00$ & $-0 / 0 Y$ & \% & ०/० & $0 / 04$ & $-0 / 0 Y$ & $Y \circ V_{0}$ & B2 \\
\hline $0 / 01$ & $0 / 04$ & $-0 / 01$ & $\circ / \circ \Delta$ & $\circ / 00$ & $\circ / 00$ & $\circ / 00$ & $\%$ & $-0 / 0 V$ & r.or & $-0 / 0 Y$ & $0 / 09$ & $0 / 0 Y$ & Y0lo & \\
\hline
\end{tabular}


بيشبينى شده است (YT و Y Y )

بحث با توجه به قرار كرفتن كشور ايران روى كمربند خشك كـره زمين و دارا بودن اقليم خشك و نيمه خشك، تأثيرات بِديـده تغيير اقليم و افزايش درجه حرارت بر فراسـنجهـاى اقليمسى امـرى بــيهى اسـت. اصـولاً بــراى بررسـى تغييـر اقلـيم از فراسنج هايى استفاده مىشود كه نسبت به بقيه فراسـنجهـا از

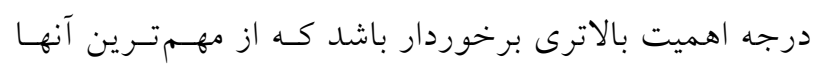

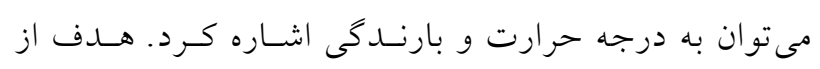
انجام تحقيق حاضر بررسى تغييرات اقليم تحت سـناريوهاى

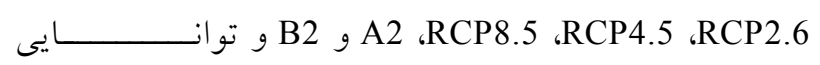

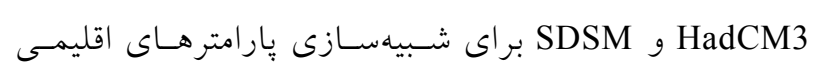
بارش، حداقل و حداكثر درجه حرارات در ايسـتخاه يـزد در

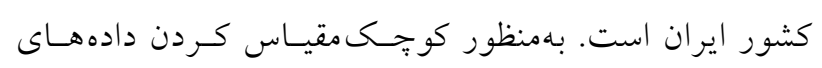
مدل گردش عمومى از مدل SDSM استفاده شده و دادههاى

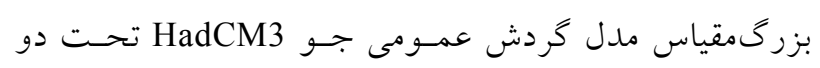

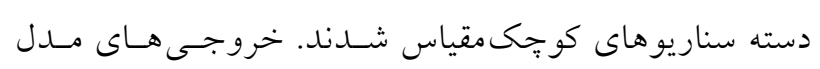
در دورههاى واسنجى و اعتبارسنجى نشان مسى دهـد

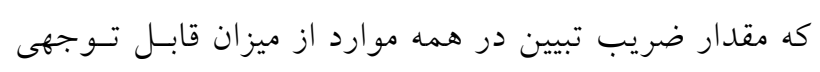
برخوردار بوده و همجنين مقادير شاخص هاى خطاسنجى نيز بهنسبت يايين بوده كه مؤيد انطباق نسبى و قابل قبول مقادير

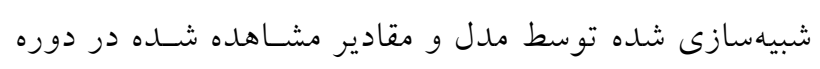
يايه است. ملاحظه مىشود كه نمودار دادههاى مشـاهداتى و

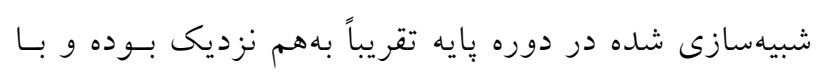

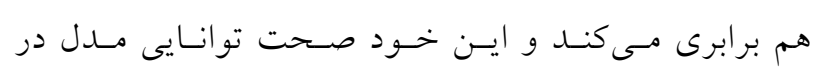
كوجىمقياس كردن دادههاى اقليمى براى آينده را تأييد مسى كند. صحت شبيهسازى دادههاى دما بالاتر از بارش است كه بـ لـ

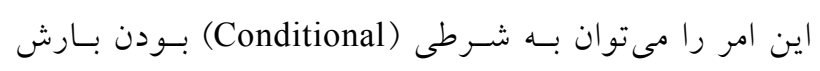

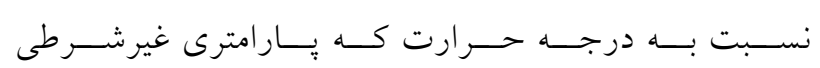
است مرتبط دانست. (Unconditional) از مدلهاى تهيه شـده در مرحلـه واسـنجى، اعتبارسـنجى و

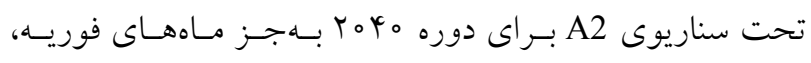

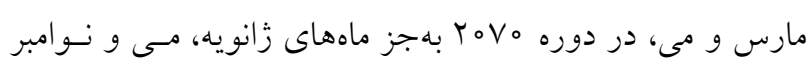

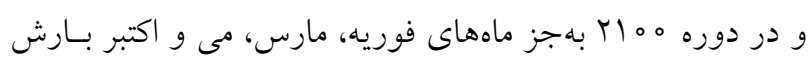

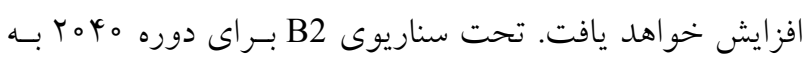

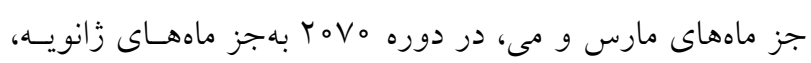

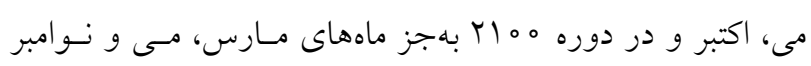
بارش افزايش خواهد يافت. اين امر نشان مىدهد كه فصلهــاى يرباران، مرطوبتر شده و فصلهاى خشك، خشكتـر خواهنــ

شكل هـاى • ا و ال او جـدول ه، مقـادير يـيشبينى شـده ميانخين دماى حداكثر روزانه تا سـال هماب تحست ســاريوهاى

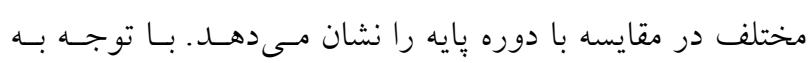
ييشبينى انجام شده براى هر سه دوره ميـانخين دمـاى حسداكثر

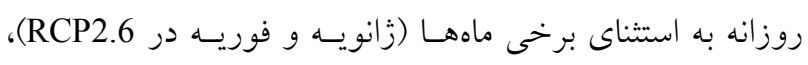

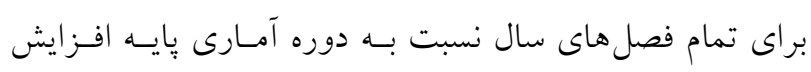

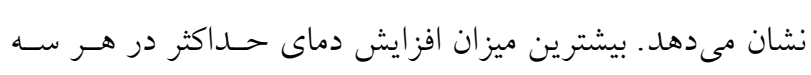
دوره آتسى مربـوط بـه سـناريوى RCP8.5 (در مـاه اوت دوره

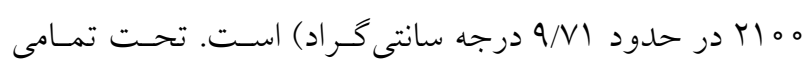
سناريوها، ميزان دماى حداكثر ماههاى گرم در مقايسه با ماههـاى

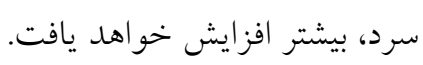

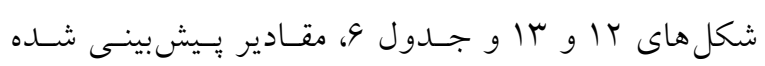

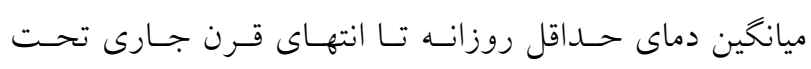
سناريوهاى مختلف در مقايسه با دوره يايه را نشـان مسى دهـــ. تحت تمامى ســاريوها، بـراى مقـدار ميـانخين دمـاى حـــاقل روزانه نسبت به مقدار متناظر دوره يايه افزايش بيش بينى شده

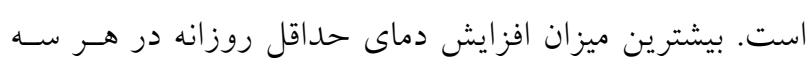
دوره آتـى مربـوط بـه سـناريوى RCP8.5 (در مـاه اوت دوره

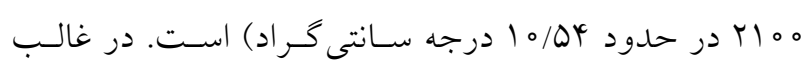
موارد، ميزان افزايش دماى حداقل در ماههاى گرم سال بيشـتر از مقدار آن در ماههاى سرد محاسبه شده است. مقايسه ميـزان

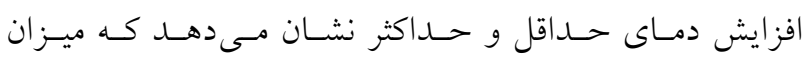

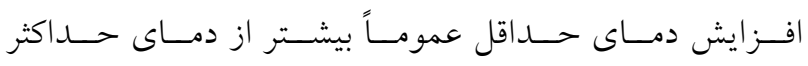




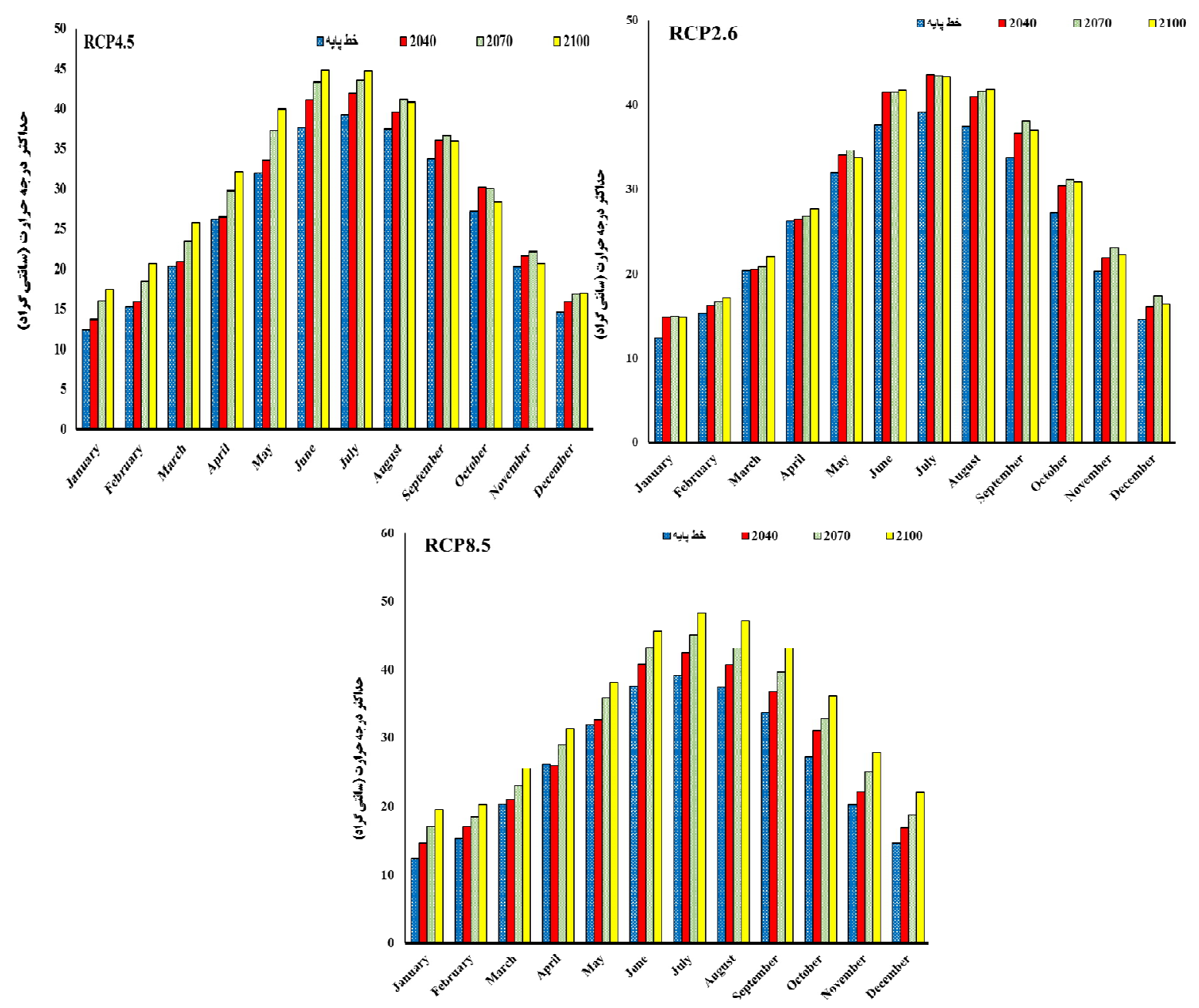

شكل ه ا. ميانخين دماى حداكثر روزانه بيشبينى شده تا بايان قرن جارى براى سناريوهاى مختلف RCPs (رنغى در نسخه الكترونيكى)

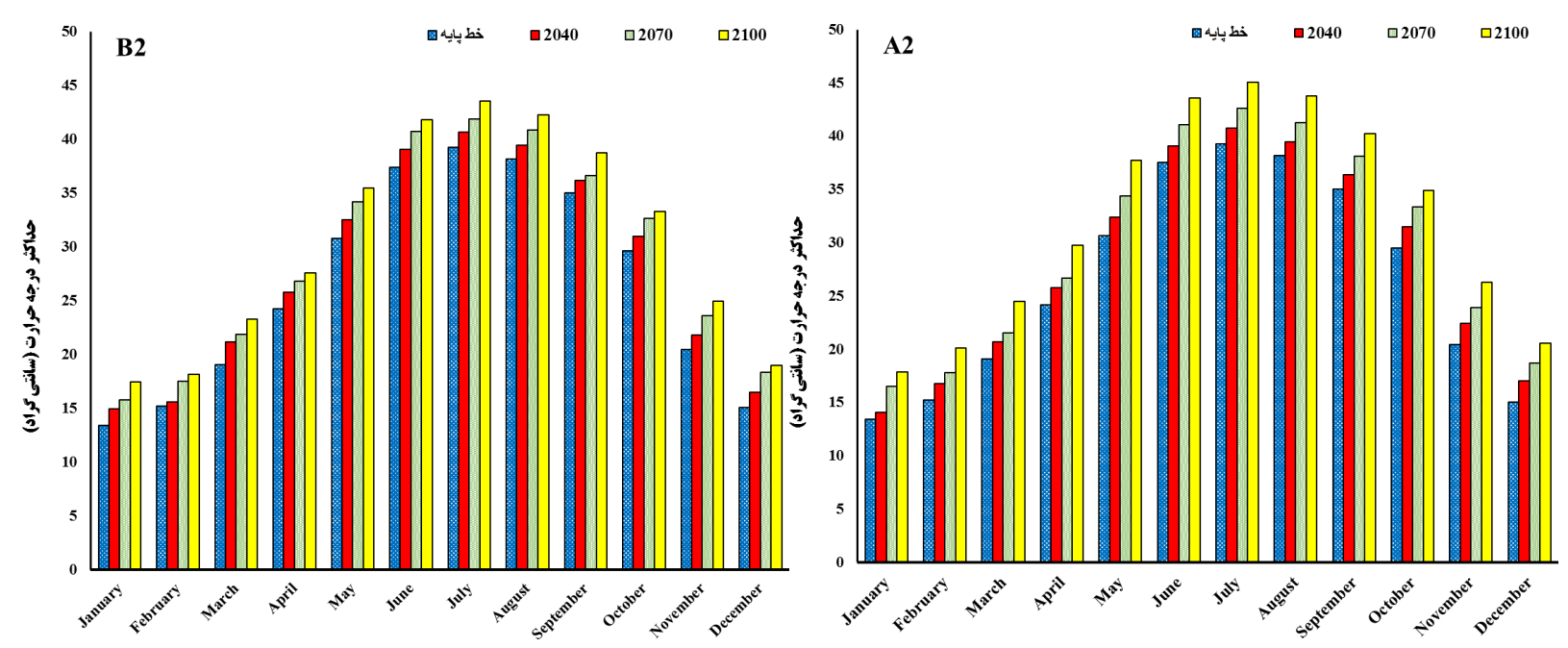

شكل 11. ميانگين دماى حداكثر روزانه بيشبينى شده تا بايان قرن جارى براى سناريوهاى مختلف SRES (رنغى در نسخه الكترونيكى) 
جدول ه. مقدار تغييرات ميانگين دماى حداكثر روزانه در در دورههاى آينده نسبت به دوره بايه تحت سناريوهاى مختلف

\begin{tabular}{|c|c|c|c|c|c|c|c|c|c|c|c|c|c|c|}
\hline سالانه & دسامبر & نوامبر & اكتبر & سبتامبر & اوت & جولاى & زوئن & مى & آوريل & مارس & فوريه & زانويه & دوره & سناريو \\
\hline$r / T \varphi$ & $1 / 40$ & $1 / 94$ & $r / r r$ & $r / \wedge 9$ & $r / \Delta r$ & $Y / A Y$ & $r / 91$ & $r / 09$ & $0 / Y 1$ & $0 / 19$ & $0 / 9 V$ & $T / Y V$ & roto & \\
\hline T/Ar & r/VG & $r / \Lambda 1$ & $r / 9 \Lambda$ & Y/Tr & $4 / 19$ & $Y / T \varphi$ & $\mathrm{r} / \mathrm{AV}$ & $r / 9 r$ & ס/gr & $0 / 40$ & $1 / \pi \wedge$ & $r / O F$ & $r \circ V_{0}$ & RCP2.6 \\
\hline$r / N r$ & $1 / A r$ & $r / \% r$ & $r / 9 r$ & $\mu / \mu_{0}$ & $r / \pi y$ & $r / T r$ & $4 / 10$ & $1 / V V$ & $1 / 4 \wedge$ & $1 / V_{0}$ & $1 / 19$ & T/AY & Yolo & \\
\hline $1 / N r$ & I/ & $1 / \pi 4$ & $r / \circ r$ & $T / Y \Lambda$ & $T / T$ & $T / N Y$ & $r / 4 r$ & $1 / \Delta \Lambda$ & $0 / 19$ & $0 / 09$ & $0 / 94$ & $1 / \pi 9$ & roto & \\
\hline$r / \Delta \Delta$ & r/Tr & $1 / 91$ & $T / \wedge \Delta$ & $r / 91$ & $r / 9 \Lambda$ & $r / \psi_{0}$ & $0 / 9 \Lambda$ & $0 / r q$ & $r / \Delta 1$ & $r / R r$ & $r / 19$ & $r / 90$ & $r \circ V_{0}$ & RCP4.5 \\
\hline$r / \mu 1$ & $r / T_{G}$ & $0 / 4 r$ & $1 / 11$ & $\Gamma / \Lambda \Lambda$ & r/ro & $\Delta / \Delta r$ & $\mathrm{~V} / \Lambda$ & V/ar & Q/AT & $0 / 4 r$ & $\Delta / \Gamma_{0}$ & $4 / 99$ & rolo & \\
\hline$T / 19$ & $T / Y^{K}$ & $1 / A K$ & $r / \Lambda F$ & $r / 0 r$ & $r / T V$ & $r / r \Lambda$ & $r / \mu r$ & $0 / 99$ & $-0 / \pi r$ & .191 & $1 / V_{0}$ & $T / Y Y$ & roYo & \\
\hline r/Gr & $4 / 10$ & $Y / A V$ & $0 / 9 \mathrm{~V}$ & $0 / 91$ & $\Delta / V^{*}$ & $\Delta / M$ & $0 / 90$ & $r / 91$ & $r / \Lambda \circ$ & T/NY & $r / r_{0}$ & $Y N 1$ & $r \circ V_{0}$ & RCP8.5 \\
\hline$V / 4$ & $\mathrm{~V} / \mathrm{N}^{\prime}$ & $V / 9 \Lambda$ & $N / q Y^{4}$ & $9 / 40$ & $9 / \mathrm{VI}$ & $9 / 1 r$ & $N /{ }^{r}$ & $9 / 11$ & D/R & $0 / T^{4}$ & $\Delta / \circ \circ$ & $V / I^{4}$ & Y.1. & \\
\hline $1 / 09$ & $r / 01$ & $1 / 99$ & $1 / 99$ & $1 / H^{\prime}$ & $1 / \pi 9$ & $1 / 49$ & $1 / 01$ & $1 / V Q$ & $1 / 94$ & $1 / \Delta \wedge$ & $1 / 01$ & $0 / 91$ & roto & \\
\hline$r / r_{0}$ & $r / q \mu$ & $r / 4 \lambda$ & $r / \Lambda 。$ & $r / \mu r$ & $r / 04$ & $\Gamma / \mu \Lambda$ & $r / 90$ & $r / v Q$ & $r / F q$ & $r / M Y$ & $r / \Delta \Lambda$ & $r / \circ V$ & $r \circ V_{0}$ & $\mathrm{~A} 2$ \\
\hline$D / D G$ & $\Delta / \Delta \circ$ & Q/AT & $\Delta / \Gamma \Lambda$ & $\Delta / r \Delta$ & $0 / 90$ & $\Delta / \Lambda 。$ & $9 / 09$ & $V / 0 G$ & D/GY & $0 / / G$ & $\psi / \wedge Q$ & $\varphi / 4 Q$ & Y.10 & \\
\hline $1 / 41$ & $1 / \Gamma \wedge$ & $1 / \pi \mu$ & $1 / x_{0}$ & $1 / 11$ & $1 / \pi 9$ & $1 / \pi 9$ & $1 / 90$ & $1 / N r$ & $1 / 09$ & $r / 11$ & O/MT & $1 / \Delta \wedge$ & roto & \\
\hline T/VG & $r / r Q$ & $r / 19$ & $r / \circ r$ & $1 / 91$ & $r / 99$ & $T / 9 T$ & $\Gamma / \mu l$ & $r / T V$ & $r / Q r$ & r/V^ & T/NT & T/YY & $r \circ V_{0}$ & B2 \\
\hline$r / 9 \Lambda$ & $r / 91$ & $\varphi / 4 \wedge$ & $r / 99$ & $r / 9 V$ & $r / \mu r$ & $r / r q$ & $Y / A r$ & $4 / 99$ & r/r & $\psi / r_{0}$ & $r / 94$ & $\varphi / 0 \varphi$ & rolo & \\
\hline
\end{tabular}
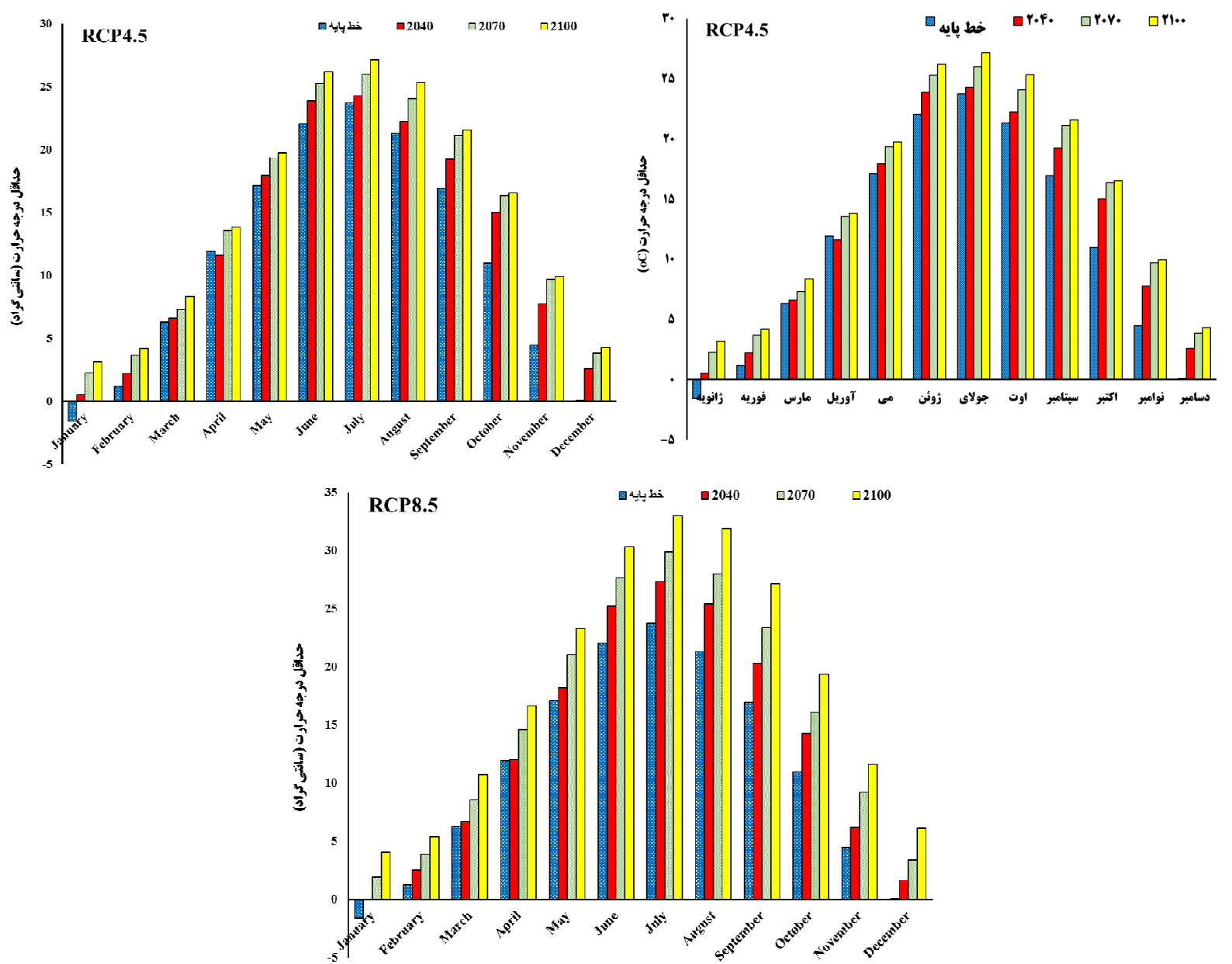

شكل r ا. ميانگين دماى حداقل روزانه بيشينى شده تا بايان قرن جارى براى سناريوهاى مختلف RCPs (رنكى در نسخه الكترونيكى) 


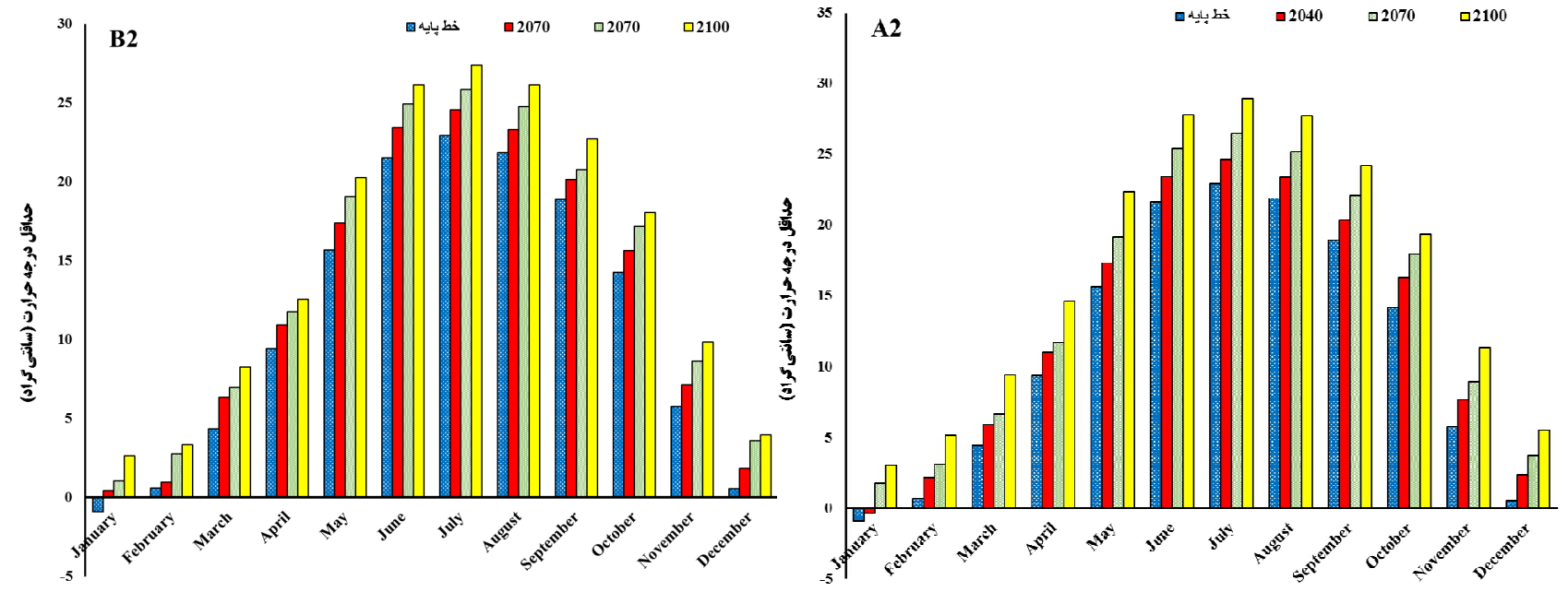

شكل rا. ميانگين دماى حداقل روزانه بيشبينى شده تا بايان قرن جارى براى سناريوهاى مختلف SRES (رنغى در نسخه الكترونيكى)

جدول 9. مقدار تغييرات ميانگين دماى حداقل روزانه در دورههاى آينده نسبت به دوره پايه تحت سناريوهاى مختلف

\begin{tabular}{|c|c|c|c|c|c|c|c|c|c|c|c|c|c|c|}
\hline سالانه & دسامبر & نو امبر & اكتبر & سيتامبر & اوت & جولاى & زوئن & مى & آوريل & مارس & فوريه & زانويه & دوره & سناريو \\
\hline$r / 19$ & $1 / 10$ & I/AT & $r / Y q$ & $\Gamma / r \Delta$ & $4 / 10$ & $\Psi / \Gamma \Lambda$ & $r / 90$ & $r / l \circ$ & D & $0 / r_{0}$ & $0 / 19$ & $1 / V \Lambda$ & roYo & \\
\hline$T / V_{0}$ & $Y / \circ \Lambda$ & $T / V V$ & $r / r V$ & $\varphi / \Delta \Delta$ & $4 / 09$ & $\varphi / 0 \varphi$ & r/vo & $r / 94$ & $\circ N Q$ & $0 / 4 r$ & $1 / \pi r$ & $1 / 99$ & $r \circ V_{0}$ & RCP2.6 \\
\hline$r / 09$ & $1 / \pi q$ & $Y / \circ \Lambda$ & $\Gamma / \Lambda$ & $r / g r$ & $r / \Lambda 1$ & $\varphi /{ }^{4}$ & r/A & $1 / 9 r$ & $1 / \pi y$ & $1 / T Q$ & $1 / 0 r$ & l/Ar & Y. 10 & \\
\hline $1 / 94$ & $r / 0_{0}$ & $\mu / \mu_{0}$ & $4 / 0 q$ & $T / \mu r$ & $0 / 91$ & $\circ /\left.\Delta\right|^{C}$ & l/Ar & o/Ar & $-0 / \pi \Delta$ & $0 / \mu 1$ & $1 / 0 Y$ & $r / \circ \Lambda$ & roYo & \\
\hline$\Gamma / \Lambda \Lambda$ & $r / V^{c}$ & $\Delta / r I$ & $D / A Y$ & $4 / 19$ & T/VG & $T / T G$ & $r / T Y$ & $T / Y V$ & $1 / 94$ & $0 / 99$ & $r / 4 q$ & ґ/A & $r_{0} V_{0}$ & RCP4.5 \\
\hline$r / \Lambda r$ & $r / r)$ & $\Delta / \mathcal{E V}$ & $0 / 09$ & $y / 94$ & $\varphi / \circ 。$ & $r / 4 r$ & $4 / 10$ & $r / 90$ & $1 / 90$ & $Y / \circ D$ & $r / 9 V$ & $r / V V$ & Y.1. & \\
\hline$r / 11$ & $1 / 01$ & $|/ N|$ & $r / r \Lambda$ & $r / r^{\prime}$ & $r / \pi r$ & $r / \Delta H^{r}$ & $r / 10$ & $1 / 10$ & 0109 & $0 / \mu \Lambda$ & $1 / \Gamma_{0}$ & $1 / 0 V^{4}$ & roYo & \\
\hline$\varphi / 4 \varphi$ & $r / \mu l$ & YNG & $\Delta / \Lambda \Lambda$ & $9 / 49$ & $9 / 91$ & $9 / 1 \pi$ & $\Delta / \Delta \Lambda$ & $r / q V$ & $r / 99$ & $r / r V$ & $r / 9 \Lambda$ & $r / 4 \varphi$ & $r \circ V_{0}$ & RCP8.5 \\
\hline$V / I I$ & $9 / 04$ & $V / I V$ & $1 / r q$ & $10 / \pi r$ & $10 / 04$ & $9 / 49$ & $\Lambda / T \Delta$ & $9 / 11$ & $4 / 9 \mathrm{~V}$ & $r / 4 k$ & $r / r_{0}$ & $0 / 94$ & r.1. & \\
\hline $1 / 90$ & I/AK & $1 / 19$ & $T / T$ & $1 / 4 V$ & $1 / 49$ & $1 / N 1$ & $1 / V 9$ & $1 / V 0$ & $1 / 94$ & $1 / 49$ & $1 / 00$ & .09 & roro & \\
\hline$r / 10$ & $\Gamma / \Lambda$ & $r / r_{0}$ & $r / V^{*}$ & $\Gamma / \Lambda$ & $r / \mu l$ & $r / \Delta \omega$ & $r / v G$ & $r / \Delta \varphi$ & T/MT & $r / r \mu$ & $T / K Y$ & $r / 9 \Lambda$ & $r \circ V \circ$ & $\mathrm{A} 2$ \\
\hline$\Delta / \Gamma V$ & $Q / \circ 。$ & $D / Q Y$ & $Q / Y I$ & $\Delta / \mu T$ & Q/AT & $0 / 99$ & $9 / 10$ & $9 / v q$ & $\Delta / r \Delta$ & $4 / 9 \Lambda$ & $\varphi / \uparrow \wedge$ & $r / q r$ & Y. 10 & \\
\hline $1 / 4 \varphi^{4}$ & $1 / \Gamma \Lambda$ & $1 / \pi q$ & $1 / \mu \lambda$ & $1 / Y^{F}$ & $1 / 49$ & $1 / 91$ & $1 / 94$ & $1 / V^{*}$ & $1 / 01$ & $r / 01$ & $0 / \mu \Lambda$ & $1 / \pi T$ & $r \circ \psi_{0}$ & \\
\hline$T / V_{0}$ & $r / \circ \mu$ & $r / 90$ & $r / 9 \circ$ & $1 / A V$ & $r / Q_{0}$ & $r / \wedge 9$ & $r / x r$ & $r / \mu V$ & T/RQ & $r / 90$ & $r / 19$ & $1 / 91$ & $r \circ V_{0}$ & B2 \\
\hline r/AG & $r / \varepsilon_{0}$ & $\varphi / 0 q$ & $r / v q$ & r/Nl & $\varphi / r \Lambda$ & $r / \mu r$ & $r / 9 T$ & $r / 90$ & $r / \mu^{*}$ & $r / q_{0}$ & T/VQ & $r / 0 q$ & Y.10 & \\
\hline
\end{tabular}


نتايج بهدست آمله حاكى از افزايش دمـا در تمـام مـاههـا و فصول سال و كاهش بارندگى در اكثر آنها است كه ايسن مسـئله مؤيد اين مطلب است كه در منطقه مورد مطالعه اقلـيم در حسال تغيير است و گرمايش جهانى در حال وقوع است. افزايش دما و تغييرات يُرامترهاى اقليمى تحت سناريوهاى مختلـف خـزارش شده است (و، ال و و TV) كه با نتايج بهدست آمده در اين تحقيق همخوانى دارد. همجين با تحقيقى كه در جِين انجام شده استـ از نظر قابليت بهتر سناريوهاى RCP مبنى بر بيشبينى بـارش و درجه حرارات، همسو است (هم).

\section{تتيجه كيرى}

نتايج عدم قطعيت در فراسنجهاى بيشبينى شده در مدل گردش عمومى نشان مى دهد كه بهطور كلى هر جّه يِيشبينى ها بهطـرف دهاهاى انتهايى قـرن حاضـر نزديـك مسىشـود عـدم قطعيـت بيشبينى ها افزايش مىيابد. نتايج بهدست آمده حاكى از افزايش دما در تمام ماهها و فصلهاى سال و كـاهش بارنـدكى در اكثر

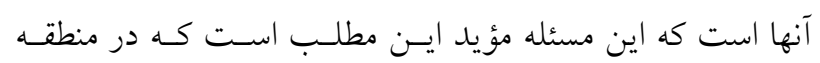
مورد مطالعه اقليم در حال تغييـر اسـت و كرمـايش جهـانى در حال وقوع است. در بزّوهش حاضر تغييرات اقلسم در ايستخاه يزد با فرض ثابت بودن شيب، يوشش كياهى و كاربرى اراضسى

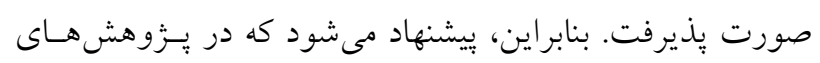

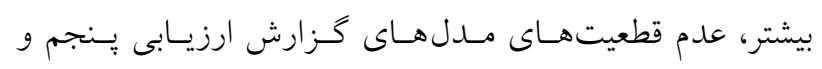
جهارم، با درنظر كرفتن همه عو امل محيطى فـوق و بـهمنظـور درى بهترى تغييرات اقليم آتى در سرتاسـر منطقسه فـوق انجـام

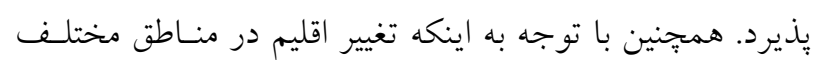

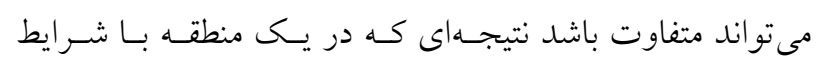
خاص بهدست مى آيد را نمىتوان به يك منطقه ديخر تعميم داد. بنابراين، به منظور مقايسه نتايج اين يزوهش با تحقيقـات انجـام

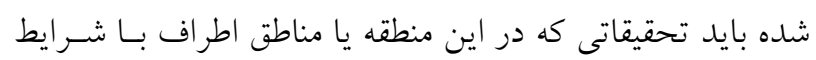
مشابه انجام شده است، ارزيابى شود.
همجنين دادههاى اقليمى بزرگ مقياس HadCM3 و ريزمقيـاس نمايى SDSM تحت سناريوهاى RCP2.6، RCP4.5، RCP8.5، A2 و B2 براى بيشبينى دورههـاى آتسى مـورد استفاده قـرار كرفت كه بر اساس نتايج بهدست آمله، بيشترين كـاهش بـارش

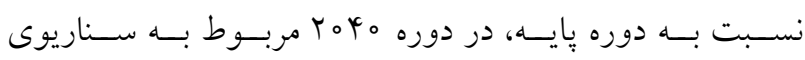

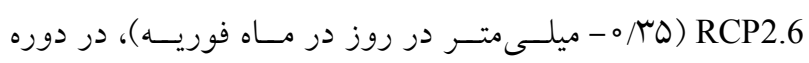
roV。

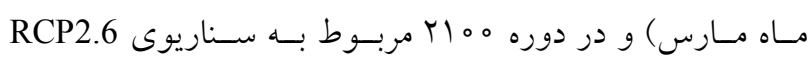
(ه//ه-ميلى متر در روز در ماه فوريه) است. نتايج تحقيق (19) در پاكستان نشاندهنده كاهش بارش تحست سـناريوى RCP2.6 به ميزان 9 درصد است. بيشترين افزايش دماى حداكثر نسبت به دوره يايسه، در دوره مربوط به سناريوى RCP2.6

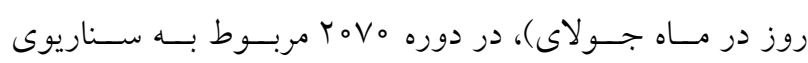

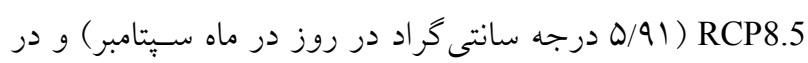
دوره مo إ مربوط به سـناريوى RCP8.5 ) كراددر روز در ماه اوت) است. بيشترين افزايش دمـاى حسداقل

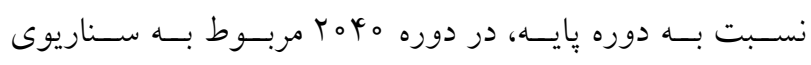

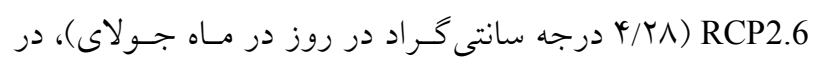

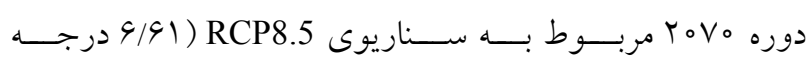

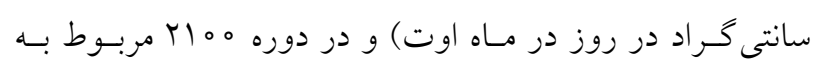

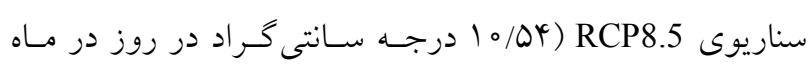

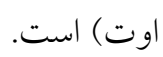
بيشبينى ها نشان مى دهد كه ميانخين دماى حداقل و حداكثر

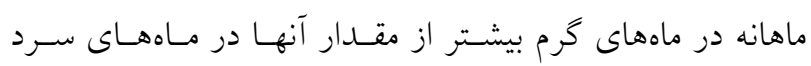

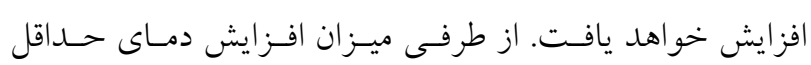
بيشتر از افزايش دماى حداكثر بـوده و ميـانخين افـزايش دمـاى

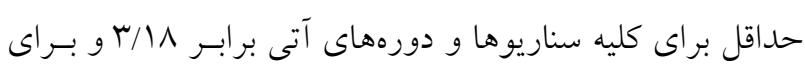

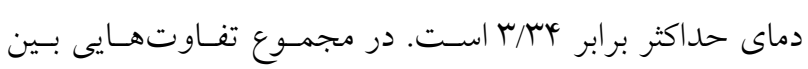

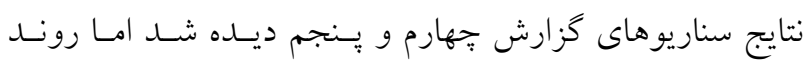
تغييرات يكسان است. 
1. Abbasnia, M., and H. Toros. 2016. Future changes in maximum temperature using the statistical downscaling model (SDSM) at selected stations of Iran. Model. Earth Systems and Environment 2: 68.

2. Abbasnia, M., T. Tavousi and M. Khosravi. 2016. Assessment of future changes in the maximum temperature at selected stations in Iran based on HADCM3 and CGCM3 models. Asia-Pacific Journal of Atmospheric Sciences 52(4): 371-377.

3. Brayson, R. A. 1997. The paradigm of climatology: an essay. Bulletin of the American Meteorological Society 73 : 449-465.

4. Chadwick, R., I. Boutle and G. martin. 2013. Spatial patterns of precipitation change in CMIP5: Why the rich do not get richer in the tropics. Journal of Climate 26(11): 3803-3822.

5. Charron, I. 2016. A Guidebook on Climate Scenarios: Using Climate Information to Guide Adaptation Research and Decisions 2016 Edition, Ouranos.

6. Chen, H., J. Guo, Z. Zhang and Ch. Xu. 2013. Prediction of temperature and precipitation in Sudan and South Suda by using LARS-WG in future. Theor Applied Climatology 113: 363-375.

7. Chou, C., J. Neelin, C. Chen and J. Tu. 2009. Evaluating the "rich-getricher" mechanism in tropical precipitation change under global warming. Journal of Climate 22(8): 1982-2004.

8. Coulibaly, P., and B. Yonas. 2005. Downscaling precipitation and temperature with temporal neural networks. American Meterology Socity 6: 483-496.

9. Dibike, Y. and P. Coulibaly. 2005. Hydrological impact of climate change in the Saguenay watershed: Comparison of downscaling methods and hydrologic models. Journal of Hydrology 307: 145-163.

10. Held, I. M. and B. J. Soden. 2006. Robust responses of the hydrological cycle to global warming. Journal of Climate 19(21): 5686-5699.

11. Huang, J., X. Guan and F. Ji. 2012. Enhanced cold-season warming in semi-arid regions. Atmospheric Chemistry and Physics 12(12): 5391-5398.

12. Javan, K., F. Nasiri Saleh and H. Taheri Shahraiyni. 2013. The influences of climate change on the runoff Gharesoo River Watershed. Climatic Change 2(4): 296-305.

13. Ji, F., Z. Wu, J. Huang and P. Eric. 2014. Evolution of land surface air temperature trend. Nat Clim Change 4: 462466.

14. Jiang, Z. H., W. L. Chen, J. Song and J. Wang. 2009. Projection and evaluation of the precipitation extremes indices over China based on seven IPCC AR4 coupled climate models. Chinese Journal of Atmospheric Sciences 33(1): 109-120.

15. Khan, M. S., P. Coulibaly and Y. Dibike. 2006. Uncertainty analysis of statistical downscaling methods using Canadian Global Climate Model predictors. Hydrology Process 20: 3085-3104.

16. Kharin, V. V. and F. W. Zwiers. 2000. Changes in the extremes in an ensemble of transient climate simulations with a coupled atmosphere-ocean GCM. Journal of Climate 13: 3760-3788.

17. Koukidis, E. N. and A. A. Berg. 2009. Sensitivity of the Statistical Downscaling Model (SDSM) to reanalysis products. Atmosphere-Ocean 47(1): 1-18.

18. Kumarbal, P., A. Ramachandran, R. Geetha, B. Bhaskaran, P. Thirumurugan, J. Indumathi and N. Jayanthi. 2016. Climate change projections for Tamil Nadu, India: deriving highresolution climate data by a downscaling approach using PRECIS. Theoretical and Applied Climatology 123(3-4): 523-535.

19. Mahmood, R., Sh. Jia. N. Kumar Tripathi and S. Shrestha. 2018. Precipitation extended linear scaling method for correcting GCM precipitation and Its evaluation and implication in the transboundary Jhelum River basin. Atmosphere 9: 160.

20. Moss, R. H., J. A. Edmonds, K. A. Hibbard et al. 2010. The next generation of scenarios for climate change research and assessment. Nature 463(7282): 747-756.

21. Nkomozepi, T. and S. O. Chung. 2014. The effect of climate change on the water resources of the Geumho River Basin, Republic of Korea. Journal of Hydro-Environment Research 8(4): 358-366.

22. Peng, S. B., J. L. Huang, J. E. Sheehy, R. C. Laza, R. M. Visperas, X. H. Zhong, G. S. Centeno, G. S. Khush and K. G. Cassman. 2004. Rice yields decline with higher night temperature from global warming. Proceedings of the National Academy of Sciences, U.S.A 101: 9971-9975.

23. Peterson, T. C., X. B. Zhang, M. B. India and J. L. V. Aguirre. 2008. Changes in North American extremes derived from daily weather data. Journal of Geophysical Research 41: 123-135.

24. Salathe, E. P. 2005. Downscaling simulations of future global climate with application to hydrologic modeling. International Journal of Climatology 25: 419-436.

25. Seager, R., N. Naik and G. A. Vecchi. 2010. Thermodynamic and dynamic mechanisms for large-scale changes in the hydrological cycle in response to global warming. Journal of Climate 23(17): 4651-4668. 
26. Solomon, S., D. Qin, M. Manning, Z. Chen, M. Marquis, K. B. Averyt, M. Tignor and H. L. Miller. 2007. The Physical science basis, contribution of working group I to the Fourth assessment report of the intergovernmental panel on climate change. Cambridge University Press, Ambridge 1-18.

27. Terink, W., W. W. Immerzeel and P. Droogers. 2013. Climate change projections of precipitation and reference evapotranspiration for the Middle East and Northern Africa until 2050. International Journal of Climatology 33(14): 3055-3072.

28. Turkes, M. and U. M. Sumer. 2004. Spatial and temporal patterns of trends and variability in diurnal temperature ranges of Turkey. Theoretical and Applied Climatology 77: 195-227.

29. UNEP. 2000. IPCC Emissions Scenarios, in IPCC SRES 2000.

30. Vuuren, D. V., J. Edmonds, M. Kainuma, K. Riahi and J. Weyant. 2011. A special issue on the RCPs. Climate Change 109: 1-4.

31. Wang, Q-x., X-h. Fan, Z-d. Qin and M-b. Wang. 2012. Change trends of temperature and precipitation in the loess plateau region of China, 1961-2010. Global and Planetary Change 138-147.

32. Wilby, R. L. and C. W. Dawson. 2007. SDSM 4.2-A Decision Support Tool for the Assessment of Regional Climate Change Impacts, Version 4.2 User Manual. Lancaster University, Lancaster/Environment Agency of England and Wales, Lancaster.

33. Wilby, R. L., C. W. Dawson and E. M. Barrow. 2002. SDSM-A decision support tool for the assessment of regional climate change impacts. Environmental Modelling and Software 17: 147-159.

34. Wilby, R. L., O. J. Tomlinson and W. C. Dawson. 2003. Multi-site simulation of precipitation by conditional resampling. Journal of Climate Research 23: 183-194.

35. Xu, C. H. and Y. Xu. 2012. The projection of temperature and precipitation over China under RCP scenarios using a CMIP5 multi-model ensemble. Atmospheric and Oceanic Science Letters 5(6): 527-533.

36. Zhao, Z. C., Y. Luo, Y. Jiang and Y. Xu. 2008. Projections of surface air temperature change in China for the next two decades. Journal of Meteorological Research 24(5): 1-5. 


\title{
Evaluation of the Effects of Climate Change on Meteorological Parameters under Different Scenarios in Yazd Meteorological Station
}

\author{
H. Fathizad ${ }^{1 *}$, M. Tavakoli ${ }^{2}$, M. A. Hakimzadeh Ardakani ${ }^{1}$, R. TaghizadehMehrjardi ${ }^{3}$ \\ and $\mathrm{H}$. Sodaiezadeh ${ }^{1}$
}

(Received: December 6-2019 ; Accepted: June 16-2020)

\begin{abstract}
The purpose of this research was to investigate the trend of annual changes in Yazd station's meteorological parameters including minimum and maximum average daily temperature and average daily precipitation (1961-2005), as well as the predicted annual mean of these parameters in the three upcoming thirty years of the $2040 \mathrm{~s}, 2070 \mathrm{~s}$ and $2100 \mathrm{~s}$, by the SDSM model, under RCP2.6, RCP4.5, RCP8.5, A2, and B2 scenarios. Accordingly, by using the coefficient of determination and the MAE, $\mathrm{R}^{2}, \mathrm{RMSE}$ indicators, we evaluated the data generated by the SDSM model in comparison with the observed data in the base period. The lowest value of $\mathrm{R}^{2}$ based on the calibration and validation of the mean values of observed and simulated SRES was obtained for precipitation ( 86 and $80 \%$ ). In terms of the $\mathrm{R}^{2}$ evaluation index, the accuracy of the small-scaled results of the minimum and maximum average temperature values was more than that of the average precipitation; however, in terms of the MAE and RMSE evaluation indicators, the accuracy of the small-scaled results of the average precipitation was higher than that of the minimum and maximum average temperature values. Subsequently, HadCM3 large-scale climatological data was used to predict the future periods (2010-2100). The results indicated that the temperature was raised in all months and seasons and the precipitation was decreasing in most of them, thereby confirming that the climate was changing in the studied region.
\end{abstract}

Keywords: Climate Change, HadCM3, SDSM, Yazd, Iran.

1. Department of Management Arid and Desert Regions, College of Natural Resources and Desert, Yazd University, Iran.

2. Natural Resources Department, Agriculture Faculty, Ilam University, Ilam, Iran.

3. Department of Soil Science, Agriculture and Natural Resources Department, Ardakan University, Yazd, Iran.

*: Corresponding author, Email: H.fathizad@stu.yazd.ac.ir 